\title{
Plant functional type mapping for earth system models
}

\author{
B. Poulter ${ }^{1,2}$, P. Ciais ${ }^{2}$, E. Hodson ${ }^{1}$, H. Lischke ${ }^{1}$, F. Maignan $^{2}$, S. Plummer ${ }^{3}$, and N. E. Zimmermann ${ }^{1}$ \\ ${ }^{1}$ Swiss Federal Research Institute WSL, Dynamic Macroecology, Zürcherstrasse 111, Birmensdorf 8903, Switzerland \\ ${ }^{2}$ Laboratoire des Sciences du Climat et de L'Environment, UMR8212, CNRS - CEA, UVSQ, Gif-sur Yvette, France \\ ${ }^{3}$ IGBP-ESA Joint Projects Office, c/o ESA-ESRIN, European Space Agency, Via Galileo Galilei, 00044, Frascati, Italy
}

Received: 26 July 2011 - Published in Geosci. Model Dev. Discuss.: 26 August 2011

Revised: 4 November 2011 - Accepted: 8 November 2011 - Published: 16 November 2011

\begin{abstract}
The sensitivity of global carbon and water cycling to climate variability is coupled directly to land cover and the distribution of vegetation. To investigate biogeochemistryclimate interactions, earth system models require a representation of vegetation distributions that are either prescribed from remote sensing data or simulated via biogeography models. However, the abstraction of earth system state variables in models means that data products derived from remote sensing need to be post-processed for model-data assimilation. Dynamic global vegetation models (DGVM) rely on the concept of plant functional types (PFT) to group shared traits of thousands of plant species into usually only 10-20 classes. Available databases of observed PFT distributions must be relevant to existing satellite sensors and their derived products, and to the present day distribution of managed lands. Here, we develop four PFT datasets based on land-cover information from three satellite sensors (EOSMODIS $1 \mathrm{~km}$ and $0.5 \mathrm{~km}$, SPOT4-VEGETATION $1 \mathrm{~km}$, and ENVISAT-MERIS $0.3 \mathrm{~km}$ spatial resolution) that are merged with spatially-consistent Köppen-Geiger climate zones. Using a beta (ß) diversity metric to assess reclassification similarity, we find that the greatest uncertainty in PFT classifications occur most frequently between cropland and grassland categories, and in dryland systems between shrubland, grassland and forest categories because of differences in the minimum threshold required for forest cover. The biogeographybiogeochemistry DGVM, LPJmL, is used in diagnostic mode with the four PFT datasets prescribed to quantify the effect of land-cover uncertainty on climatic sensitivity of gross primary productivity (GPP) and transpiration fluxes. Our results show that land-cover uncertainty has large effects in arid regions, contributing up to $30 \%(20 \%)$ uncertainty in the sensitivity of GPP (transpiration) to precipitation. The
\end{abstract}

Correspondence to: B. Poulter (benjamin.poulter@1sce.ipsl.fr) availability of PFT datasets that are consistent with current satellite products and adapted for earth system models is an important component for reducing the uncertainty of terrestrial biogeochemistry to climate variability.

\section{Introduction}

Terrestrial biogeography holds a key role in determining spatial patterns of biogeochemical cycling (Olson et al., 1983), biodiversity (Kleidon et al., 2009) and the consumption and production of natural resources (Foley et al., 2005; Haberl et al., 2007). An improved understanding of global biogeography is required to provide a baseline for assessing the vulnerability of the carbon and water cycle and other ecosystem processes related to ongoing global change. Such baselines are also relevant to earth system modeling research, especially for dynamic global vegetation modeling (DGVM), with applications extending to model initialization, optimization, and benchmarking (Plummer, 2000). However, available remotely-sensed datasets for land cover show large variability (Giri et al., 2005), partly due to differences in data retrieval (i.e., satellite properties) and partly because there is no standard approach to classifying continuous vegetation cover into discrete categories. In addition, to be comparable to plant functional type (PFT) definitions used by DGVM models, land-cover legends must be cross-walked (reclassified) to broader PFT categories (Jung et al., 2006). To address the variability between land-cover products and the challenges of cross-walking land-cover legends, we developed a methodology to process an ensemble of PFT datasets corresponding to the most common global land-cover products available. In our analysis, the pattern and drivers of variability across this ensemble is quantitatively assessed and attributed to interpret the effects of land-cover uncertainty on biogeochemical fluxes.

Published by Copernicus Publications on behalf of the European Geosciences Union. 
Table 1. Characteristics of the remotely sensed land cover datasets used to develop the phenology, physiognomy, and natural/managed traits for the PFT mapping.

\begin{tabular}{|c|c|c|c|c|c|c|c|c|}
\hline $\begin{array}{l}\text { Land cover } \\
\text { product }\end{array}$ & $\begin{array}{l}\text { Satellite and } \\
\text { sensor type }\end{array}$ & $\begin{array}{l}\text { Time } \\
\text { period }\end{array}$ & $\begin{array}{l}\text { Spatial } \\
\text { resolution }\end{array}$ & $\begin{array}{l}\text { Number } \\
\text { of classes }\end{array}$ & $\begin{array}{l}\text { File size } \\
(\mathrm{GB})\end{array}$ & \# rows & \# cols & $\begin{array}{l}\text { Classification } \\
\text { accuracy }\end{array}$ \\
\hline GLC2000 v1.1 & $\begin{array}{l}\text { SPOT-4 } \\
\text { (VEGA2000) }\end{array}$ & 2000 & $1000 \mathrm{~m}$ & $\begin{array}{l}22 \text { (modified } \\
\text { UN LCCS) }\end{array}$ & 0.66 & 40320 & 16353 & $39-64 \%$ \\
\hline Mod12q1 C004 & Terra & 2001 & $1000 \mathrm{~m}$ & 17 (IGBP legend) & 0.93 & 43200 & 21600 & $75-80 \%$ \\
\hline Mod12q1 C005 & Terra & 2005 & $500 \mathrm{~m}$ & 17 (IGBP legend) & 3.47 & 86400 & 43200 & $72-77 \%$ \\
\hline GlobCover v2.2 & $\begin{array}{l}\text { Envisat } \\
\text { (Meris) }\end{array}$ & $\begin{array}{l}12-2004 / \\
06-2006\end{array}$ & $300 \mathrm{~m}$ & $\begin{array}{l}22 \text { (modified } \\
\text { UN LCCS) }\end{array}$ & 7.82 & 129600 & 64800 & $67.1 \%$ \\
\hline
\end{tabular}

There are now several (Table 1) moderate resolution global land-cover datasets available from different satellite sensors and research groups (Friedl et al., 2002, 2010; Bartholome and Belward, 2005; Arino et al., 2008) providing an opportunity to assess ensemble variability. Although these landcover datasets provide new opportunities for model-data assimilation studies to assess the effects of land-cover feedbacks (Quaife et al., 2008; Sterling and Ducharne, 2008; Jung et al., 2007), their approach for classifying land cover is not yet consistent with Earth System Model (ESM) requirements. This is because the concept of plant functional types used in ESMs cannot be mapped directly using remote sensing data since PFT traits represent a combination of spectral relationships, and climatic, ecological, and theoretical assumptions (Smith et al., 1997; Sun et al., 2008; Running et al., 1995; Ustin and Gamon, 2010). The PFT concept consists of aggregating multiple species traits, allowing for the reduction of thousands of species to a small set of functional groups (typically $<15$ ) defined by their phenology type, physiognomy, photosynthetic pathway, and climate zone. The advantage of the PFT classification system is that it allows the possibility for posing testable hypotheses that are feasible at global and centennial scales (Smith et al., 1997).

Existing PFT datasets include those by Bonan et al. (2002) for the Community Land Model, with updates from (Lawrence and Chase, 2007), by Verant et al. (2004) for the Orchidee DGVM, and by Lapola et al. (2008) for the SSiB model. Improvements to these PFT datasets are currently needed to expand the availability of land-cover datasets to allow consistency with a more complete set of satellite sensors and more detailed or revised climate zone data, and to take into account current human land-use patterns. For example, Bonan et al. (2002) used multiple data sources to combine the IGBP-DISCover Global Land Cover Classification data (IGBP GLCC) and phenology-type data (from 1992-1993 AVHRR data) with vegetation continuous fields from DeFries et al. (2000). They assigned biome types from bioclimatic definitions provided by Prentice et al. (1992) based on gridded climate data from Legates and Wilmott (1990), creating one of the first ESM-relevant PFT legends (Table 2) for the Community Land Model 3.0 (Dickinson et al., 2006). In comparison, Verant et al. (2004) combined simplified Olson biomes with IGBP GLCC data to create a PFT map for the Orchidee DGVM (Krinner et al., 2005). Lapola et al. (2008) developed a global PFT map by reclassifying legends from Olson et al. (1983) and Matthews (1983) and filling areas of mismatch with regional land cover information. A different PFT legend accompanies the MODIS land cover product using categories defined by Running et al. (1995) and has been developed from GLC2000 (Wang et al., 2006). For these particular PFT legends, the classifications include phenology type but not the associated climate zone, which is needed to assign climate-specific physiological parameters to each PFT (i.e., Sitch et al., 2003). As a consequence, vegetation models using these particular PFT datasets must assume that biochemical and biophysical PFT parameters are constant globally across different climate zones (e.g., see Alton et al., 2009).

Our study contributes to ESM and DGVM modeling by developing four global PFT datasets (Table 1) using a consistent methodology applied to satellite data that vary by sensor (spatial and spectral resolution), classification system, and time period. The Köppen-Geiger climate classification scheme is used to associate physiognomy and phenology type with climate zone, and the pattern of uncertainty among the four classification systems is evaluated using a beta diversity metric. We provide an example of the importance of land-cover uncertainty on land-surface climate sensitivity by prescribing vegetation types and analyzing biogeochemistry with the LPJmL DGVM. In this experiment, we quantify the sensitivity of water and carbon fluxes to climate biogeochemical fluxes highly modified by human activities (Oki and Kanae, 2006; Schimel et al., 2001) - and evaluate how land-cover uncertainty alters these relationships. 
Table 2. Plant functional types (PFT) used in the Orchidee, LPJ and CLM dynamic global vegetation models. The PFTs are defined by biome and by phenology, followed by temperature criteria (here shown from Sitch et al., 2003) for establishment $\left(T_{\min } / T_{\max }\right.$, in ${ }^{\circ} \mathrm{C}$, are calculated from twenty year annual means).

\begin{tabular}{|c|c|c|c|c|}
\hline $\begin{array}{l}\text { Plant Functional Type (PFT) used in } \\
\text { LPJmL and Orchidee and CLM } \\
\text { (PFT code in parentheses) }\end{array}$ & Biome & $\begin{array}{l}\text { Phenology Class } \\
\text { (phenology code } \\
\text { in parentheses) }\end{array}$ & $T_{\min }$ & $T_{\max }$ \\
\hline Tropical broadleaf evergreen ( $\mathrm{TrBe})$ & \multirow{2}{*}{ Tropical } & Broadleaf evergreen (BrEv) & 15.5 & - \\
\hline Tropical raingreen ( $\mathrm{TrRg}$ ) & & Broadleaf deciduous (BrDe) & 15.5 & - \\
\hline Temperate needleleaf evergreen $(\mathrm{TeNe})$ & \multirow{3}{*}{ Temperate } & Needleleaf evergreen (NeEv) & -2 & 22.2 \\
\hline Temperate broadleaf evergreen ( $\mathrm{TeBe})$ & & Broadleaf evergreen (BrEv) & 3.0 & 18.8 \\
\hline Temperate broadleaf summergreen (TeBs) & & Broadleaf deciduous (BrDe) & -17.0 & 15.5 \\
\hline Boreal needleleaf evergreen (BoNe) & \multirow{3}{*}{ Boreal } & Needleleaf evergreen (NeEv) & - & -2 \\
\hline Boreal needleleaf summergreen (BoNd) & & Needleleaf deciduous (NeDe) & - & -2 \\
\hline Boreal broadleaf summergreen (BoBs) & & Broadleaf deciduous (BrDe) & - & -2 \\
\hline Temperate herbaceous (NatGrassC3) & Temperate & Grass & - & 15.5 \\
\hline Tropical herbaceous (NatGrassC34) & Tropical & Grass & 15.5 & - \\
\hline Managed grass C3 (MGrassC3) & Temperate & Grass & - & 15.5 \\
\hline Managed grass C4 (MGrassC4) & Tropical & Grass & 15.5 & - \\
\hline
\end{tabular}

\section{Methods}

\subsection{Land cover and climate zone datasets}

Land-cover datasets, described in Table 1, were manually reclassified to PFT specific phenology type and physiognomic categories. The resulting categories were merged with climate zones defined by the Köppen-Geiger classification system to resolve to PFT classes. The merged dataset was aggregated to $0.5^{\circ}$ spatial resolution (corresponding to the climate and soils data used in LPJmL), representing the fractional abundance of PFT mixtures within a grid cell. All analyses were conducted at the global scale in Plate-Carrée (WGS84) projection, area correcting grid cells during post-processing when necessary. The original land-cover datasets varied in spatial resolution, time period of data collection, classification approach, and accuracy and are discussed below.

The Köppen-Geiger dataset was created by Peel et al. (2007) from over 4000 metrological stations contained in the Global Historical Climatological Network v2.0 database. The authors calculated climate indices (i.e., seasonal means, minimums, and maximums) for the stations from precipitation and temperature for their entire time series (mostly, the 20th century) and then interpolated to a $0.1^{\circ}$ resolution grid (not accounting for elevation). These indices were classified into one of 32 possible climate zones (Table 3 ) according to the original Köppen-Geiger classification system (Köppen, 1936).

The GLC2000 land-cover data were generated from SPOT-VEGETATION (SPOT 4) and ATSR-2/DMSP sensors and are available for most of the vegetated surface of the globe $\left(75^{\circ} \mathrm{N}\right.$ to $56^{\circ} \mathrm{S}$, excluding Antarctica) at $1 \mathrm{~km}$ resolu- tion (Bartholome and Belward, 2005; Hugh et al., 2004). The data were collected between November 1999 and December 2000. The GLC2000 classification (Table 4) was conducted by regional expert groups following an unsupervised classification of 19 similar geographic regions using the LCCS nomenclature (22 categories for global purposes).

The GlobCover data became available in 2008 (Arino et al., 2008) and represent the highest-spatial resolution data available for global extent at this time $(0.3 \mathrm{~km}$ resolution). The classification system also follows the LCCS system (22 categories, Table 5) and the spectral data were acquired from the MERIS sensor on-board the ENVISAT satellite between June 2004 and December 2006. Individual pixels are classified using unsupervised and supervised approaches on sub-global regional clusters.

Two versions of the EOS-MODIS land cover data (MOD12Q1), V004 and V005, were used in the analysis. These differ in several aspects, including temporal coverage, spatial resolution, and classification methodology, but both use the same 17 IGBP categories (Table 6) (Friedl et al., 2010). These land-cover classes were categorized using a globally consistent supervised classification approach. V004 is available globally at $1 \mathrm{~km}$ resolution from data acquired in 2001 while V005 is available at $0.5 \mathrm{~km}$ resolution at annual resolution (starting in 2001). Both products have multiple legends available, and here we worked with the IGBP legend (Table 6), the primary MODIS legend from which the other legends are derived and most relevant for reclassifying to phenology categories (next section). 
Table 3. Köppen-Geiger biome types (Code column is defined in Peel et al., 2007) and their simplified equivalents required for DGVM PFT classification. Where $T_{\text {hot }}$ and $T_{\text {cold }}$ are temperature of the hottest and coldest month $\left({ }^{\circ} \mathrm{C}\right)$, and MAT is mean annual temperature $\left({ }^{\circ} \mathrm{C}\right)$.

\begin{tabular}{|c|c|c|c|c|}
\hline \multirow{2}{*}{$\begin{array}{l}\text { Number } \\
1\end{array}$} & \multirow{2}{*}{$\begin{array}{l}\text { Code } \\
\text { Af }\end{array}$} & \multicolumn{2}{|c|}{ Köppen-Geiger biome category } & \multirow{2}{*}{$\begin{array}{l}\text { PFT biome equivalent } \\
\text { (this study) } \\
\text { Tropical }\end{array}$} \\
\hline & & Tropical & $T_{\text {cold }}=>18$ & \\
\hline 2 & $\mathrm{Am}$ & & & \\
\hline 3 & Aw & & & \\
\hline 4 & BWh & Arid & MAT $=>18$ & \\
\hline 5 & BWk & & MAT < 18 & Temperate (warm) \\
\hline 6 & BSh & & $\mathrm{MAT}=>18$ & Tropical \\
\hline 7 & BSk & & MAT $<18$ & Temperate (warm) \\
\hline 8 & Csa & $\begin{array}{l}\text { Temperate } \\
T_{\text {hot }}>10 \\
\& T_{\text {cold }}<18\end{array}$ & $T_{\text {hot }}=>22$ & Temperate (warm) \\
\hline 9 & Csb & & & Temperate (cool) \\
\hline 10 & Csc & & & \\
\hline 11 & Cwa & & $T_{\text {hot }}=>22$ & Temperate (warm) \\
\hline 12 & Cwb & & & Temperate (cool) \\
\hline 13 & Cwc & & & \\
\hline 14 & $\mathrm{Cfa}$ & & $T_{\text {hot }}=>22$ & Temperate (warm) \\
\hline 15 & $\mathrm{Cfb}$ & & & Temperate (cool) \\
\hline 16 & $\mathrm{Cfc}$ & & & \\
\hline 17 & Dsa & $\begin{array}{l}\text { Cold } \\
T_{\text {hot }}>10 \\
\& T_{\text {cold }}<0\end{array}$ & $T_{\text {hot }}=>22$ & Boreal (warm) \\
\hline 18 & Dsb & & & Boreal (cool) \\
\hline 19 & Dsc & & & \\
\hline 20 & Dsd & & & \\
\hline 21 & Dwa & & $T_{\text {hot }}=>22$ & Boreal (warm) \\
\hline 22 & Dwb & & & Boreal (cool) \\
\hline 23 & Dwc & & & \\
\hline 24 & Dwd & & & \\
\hline 25 & Dfa & & $T_{\mathrm{hot}}=>22$ & Boreal (warm) \\
\hline 26 & Dfb & & & Boreal (cool) \\
\hline 27 & Dfc & & & \\
\hline 28 & Dfd & & & \\
\hline 29 & ET & $\begin{array}{l}\text { Polar } \\
T_{\text {hot }}<10\end{array}$ & $T_{\text {hot }}>0$ & \\
\hline 30 & $\mathrm{EF}$ & & $T_{\text {hot }}<0$ & \\
\hline $31==29$ & ETH & & & \\
\hline $32==30$ & EFH & & & \\
\hline
\end{tabular}

\subsection{Reclassifying the legends}

The land-cover data were first cross-walked (reclassified) to a phenology-based legend consistent with the plant functional types used in major DGVM and land surface models (Table 2). Figure 1 illustrates the flow of data processing, with the merging of the phenology type and climate data described in the following section. Manually reclassifying legends is inherently subjective, especially with the treatment of mixed vegetation categories where multiple possible classes must be reduced to only one class (Jung et al., 2006; Giri et al., 2005). The possible bias resulting from reclassification was handled, in part, by comparing levels of agreement among the aggregated PFT classification datasets. The comparison highlighted the spatial pattern of dissimilarity and provided a means for qualitatively evaluating the contribution of uncertainty from reclassification problems and from actual remote sensing differences. The reclassification was conducted on the original resolution of the land-cover dataset and implemented in $\mathrm{C}$ programming language. 
Table 4. The GLC2000 legend (based on LCCS) and corresponding DGVM phenology class (from Table 2).

\begin{tabular}{|c|c|c|}
\hline GLC ID & GLC2000 description & DGVM phenology class \\
\hline 1 & Tree Cover, broadleaved, evergreen & $90 \% \mathrm{BrEv}, 10 \%$ NatGrass \\
\hline 2 & Tree Cover, broadleaved, deciduous, closed & $100 \% \mathrm{BrDe}$ \\
\hline 3 & Tree Cover, broadleaved, deciduous, open (open $15-40 \%$ tree cover) & $80 \% \mathrm{BrDe}, 20 \%$ NatGrass \\
\hline 4 & Tree Cover, needle-leaved, evergreen & $100 \% \mathrm{NeEv}$ \\
\hline 5 & Tree Cover, needle-leaved, deciduous & $100 \% \mathrm{NeDe}$ \\
\hline 6 & Tree Cover, mixed leaf type & $25 \% \mathrm{BrEv}, \mathrm{BrDe}, \mathrm{NeEv}, \mathrm{NeDe}$ \\
\hline 7 & Tree Cover, regularly flooded, fresh water ( \& brackish) & $25 \% \mathrm{BrEv}, \mathrm{BrDe}, \mathrm{NeEv}, \mathrm{NeDe}$ \\
\hline 8 & Tree Cover, regularly flooded, saline water & $25 \% \mathrm{BrEv}, \mathrm{BrDe}, \mathrm{NeEv}, \mathrm{NeDe}$ \\
\hline 9 & Mosaic: Tree cover/Other natural vegetation & $20 \% \mathrm{BrEv}, \mathrm{BrDe}, \mathrm{NeEv}, \mathrm{NeDe}$, NatGrass \\
\hline 10 & Tree Cover, burnt & $25 \% \mathrm{BrEv}, \mathrm{BrDe}, \mathrm{NeEv}, \mathrm{NeDe}$ \\
\hline 11 & Shrub Cover, closed-open, evergreen & $40 \% \mathrm{BrEv}, \mathrm{NeEv}, 20 \%$ NatGrass \\
\hline 12 & Shrub Cover, closed-open, deciduous & $80 \%$ BrDe, $20 \%$ NatGrass \\
\hline 13 & Herbaceous Cover, closed-open & $100 \%$ NatGrass \\
\hline 14 & Sparse Herbaceous or sparse Shrub Cover & $60 \%$ NatGrass, $40 \%$ bare \\
\hline 15 & Regularly flooded Shrub and/or Herbaceous Cover & $10 \% \mathrm{BrEv}, \mathrm{BrDe}, \mathrm{NeEv}, \mathrm{NeDe}, 60 \%$ NatGrass \\
\hline 16 & Cultivated and managed areas & $100 \%$ ManGrass \\
\hline 17 & Mosaic: Cropland/Tree Cover/Other natural vegetation & $8 \%$ BrEv, BrDe, NeEv, NeDe, NatGrass, ManGrass \\
\hline 18 & Mosaic: Cropland/Shrub or Grass Cover & $8 \% \mathrm{BrEv}, \mathrm{BrDe}, \mathrm{NeEv}, \mathrm{NeDe}$, NatGrass, ManGrass \\
\hline 19 & Bare Areas & Bare \\
\hline 20 & Water Bodies (natural \& artificial) & Water \\
\hline 21 & Snow and Ice (natural \& artificial) & Bare \\
\hline 22 & Artificial surfaces and associated areas & Urban \\
\hline 23 & No data & No data \\
\hline
\end{tabular}

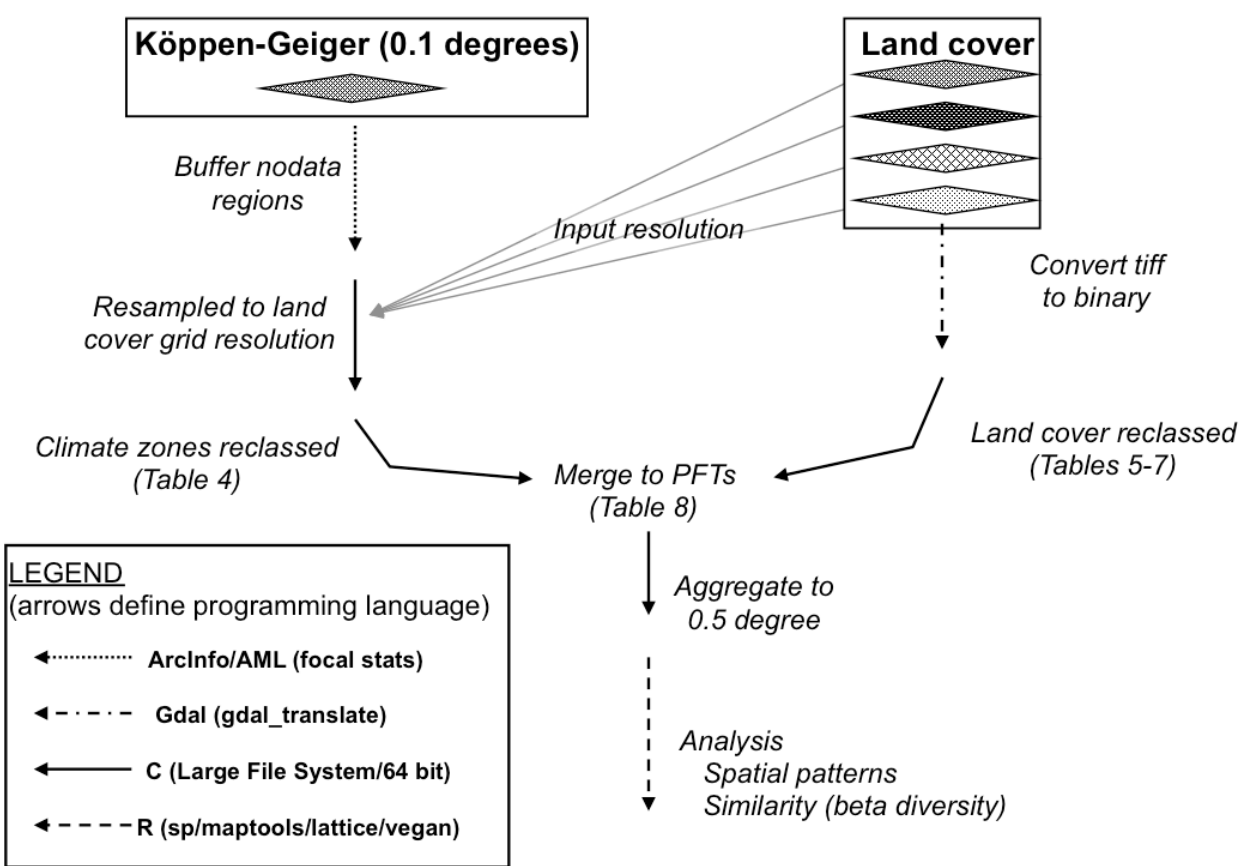

Fig. 1. Illustration of the flow of analysis and the reclassification of the climate zone data to simplified biomes, and the land-cover data to their phenology types, physiognomy and land-use counterparts. 
Table 5. The GlobCover legend (LCCS) and corresponding DGVM phenology class (from Table 2).

\begin{tabular}{|c|c|c|}
\hline ID & GlobCover description & DGVM phenology class \\
\hline 11 & Post-flooding or irrigated croplands (or aquatic) & $100 \%$ ManGrass \\
\hline 14 & Rainfed croplands & $100 \%$ ManGrass \\
\hline 20 & $\begin{array}{l}\text { Mosaic cropland (50-70\%)/vegetation } \\
\text { (grassland/shrubland/forest) }(20-50 \%)\end{array}$ & $\begin{array}{l}10 \% \text { BrEv, BrDe, NeEv, NeDe, Nat- } \\
\text { Grass, } 50 \% \text { ManGrass }\end{array}$ \\
\hline 30 & $\begin{array}{l}\text { Mosaic vegetation (grassland/shrubland/forest) } \\
(50-70 \%) / \text { cropland }(20-50 \%)\end{array}$ & $\begin{array}{l}10 \% \text { BrEv, BrDe, NeEv, NeDe, } 20 \% \\
\text { NatGrass, } 40 \% \text { ManGrass }\end{array}$ \\
\hline 40 & $\begin{array}{l}\text { Closed to open }(>15 \%) \text { broadleaved evergreen } \\
\text { or semi-deciduous forest }(>5 \mathrm{~m})\end{array}$ & $50 \% \mathrm{BrEv}, \mathrm{BrDe}$ \\
\hline 50 & $\begin{array}{l}\text { Closed }(>40 \%) \text { broadleaved deciduous } \\
\text { forest }(>5 \mathrm{~m})\end{array}$ & $100 \% \mathrm{BrDe}$ \\
\hline 60 & $\begin{array}{l}\text { Open }(15-40 \%) \text { broadleaved deciduous } \\
\text { forest/woodland }(>5 \mathrm{~m})\end{array}$ & $80 \%$ BrDe, $20 \%$ NatGrass \\
\hline 70 & $\begin{array}{l}\text { Closed }(>40 \%) \text { needleleaved } \\
\text { evergreen forest }(>5 \mathrm{~m})\end{array}$ & $100 \% \mathrm{NeEv}$ \\
\hline 90 & $\begin{array}{l}\text { Open }(15-40 \%) \text { needleleaved deciduous or } \\
\text { evergreen forest }(>5 \mathrm{~m})\end{array}$ & $40 \% \mathrm{NeEv}, \mathrm{NeDe}, 20 \%$ NatGrass \\
\hline 100 & $\begin{array}{l}\text { Closed to open }(>15 \%) \text { mixed broadleaved and } \\
\text { needleleaved forest }(>5 \mathrm{~m})\end{array}$ & $25 \% \mathrm{BrEv}, \mathrm{BrDe}, \mathrm{NeEv}, \mathrm{NeDe}$ \\
\hline 110 & $\begin{array}{l}\text { Mosaic forest or shrubland } \\
(50-70 \%) / \text { grassland }(20-50 \%)\end{array}$ & $\begin{array}{l}20 \% \text { BrEv, BrDe, NeEv, NeDe, Nat- } \\
\text { Grass }\end{array}$ \\
\hline 120 & $\begin{array}{l}\text { Mosaic grassland }(50-70 \%) / \text { forest or } \\
\text { shrubland }(20-50 \%)\end{array}$ & $\begin{array}{l}10 \% \text { BrEv, BrDe, NeEv, NeDe, } 60 \% \\
\text { NatGrass }\end{array}$ \\
\hline 130 & $\begin{array}{l}\text { Closed to open }(>15 \%) \text { (broadleaved or } \\
\text { needleleaved, evergreen or deciduous) } \\
\text { shrubland }(<5 \mathrm{~m})\end{array}$ & $\begin{array}{l}20 \% \text { BrEv, NeEv, } 10 \% \text { BrDe, NeDe, } \\
40 \% \text { NatGrass }\end{array}$ \\
\hline 140 & $\begin{array}{l}\text { Closed to open }(>15 \%) \text { herbaceous vegetation } \\
\text { (grassland, savannas or lichens/mosses) }\end{array}$ & $20 \%$ NeEv, $80 \%$ NatGrass \\
\hline 150 & Sparse $(<15 \%)$ vegetation & $40 \%$ NatGrass, $60 \%$ bare \\
\hline 160 & $\begin{array}{l}\text { Closed to open }(>15 \%) \text { broadleaved forest } \\
\text { regularly flooded (semi-permanently or } \\
\text { temporarily) - Fresh or brackish water }\end{array}$ & $33 \%$ BrEv, BrDe, NatGrass \\
\hline 170 & $\begin{array}{l}\text { Closed ( }>40 \% \text { ) broadleaved forest or } \\
\text { shrubland permanently flooded - Saline or } \\
\text { brackish water }\end{array}$ & $50 \% \mathrm{BrEv}, \mathrm{BrDe}$ \\
\hline 180 & $\begin{array}{l}\text { Closed to open }(>15 \%) \text { grassland or woody } \\
\text { vegetation on regularly flooded or waterlogged } \\
\text { soil - Fresh, brackish or saline water }\end{array}$ & $\begin{array}{l}20 \% \text { BrEv, BrDe, NeEv, NeDe, } \\
\text { NatGrass }\end{array}$ \\
\hline 190 & $\begin{array}{l}\text { Artificial surfaces and associated areas (Urban } \\
\text { areas }>50 \% \text { ) }\end{array}$ & $100 \%$ Urban \\
\hline 200 & Bare areas & $100 \%$ Bare \\
\hline 210 & Water bodies & $100 \%$ Water \\
\hline 220 & Permanent snow and ice & $100 \%$ Bare \\
\hline 230 & No data (burnt areas, clouds,...) & $100 \%$ No data \\
\hline
\end{tabular}

Tables 4, 5, and 6 list the original land-cover classes from GLC2000, GlobCover, and MODIS and their corresponding reclassification into phenology type (Table 2). Six PFTspecific phenology-type/physiognomy classes were predefined, corresponding with categories used in several DGVM models (broadleaf evergreen BrEv, broadleaf deciduous $\mathrm{BrDe}$, needleaf evergreen $\mathrm{NeEv}$, needleleaf decid- uous NeDe, natural grassland NatGrass, and managed grassland ManGrass (representing either pasture or crop)). For some categories, the reclassification was straightforward, i.e., GLC2000 "Tree cover, broadleaf, deciduous, closed" was reclassified to "broadleaf deciduous." Other categories, for example, GLC2000 "Tree cover, mixed leaf type," or MODIS IGBP "Open shrublands" did not correspond to a 
single PFT phenology/physiognomy class. In these cases, the land cover class was reclassified to one of several possible phenology-types and physiognomy classes whose probability was assigned by assessing the supplementary data regarding the legend definitions or examining the spatial pattern of observed land cover classes, and based on expert opinion on how the class might be composed of various phenology types (similar to Wang et al., 2006). In these cases, for example, a "mixed tree cover" category would yield $25 \%$ equal probability (using a uniform distribution for all mixed land cover categories) with the grid cell being reclassified to either BrEv, BrDe, NeEv, or NeDe. This approach resulted in a single category cell, but when the cells were aggregated to coarser resolution (described below), the relative PFT fractions more realistically represented the original mixed forest classes (for example, aggregating from $1 \mathrm{~km}$ mixed forest category to 0.5 degree resolution results in 0.5 degree fractions equal to 0.25 for $\mathrm{BrEv}, \mathrm{BrDe}, \mathrm{NeEv}$, and $\mathrm{NeDe}$, summing to 1.0 for an aggregated cell).

\subsection{Merging and aggregating phenology and climate zones}

The Köppen-Geiger dataset was first adjusted to expand its coastal grid cell definitions to neighboring ocean grid cells to allow a complete overlay of land cover with climate zone. The buffered Köppen-Geiger data were then downscaled to the spatial resolution of the corresponding land-cover dataset using a nearest neighbor resampling algorithm. The resampled Köppen-Geiger data were reclassified into one of three major biome types (following the rules described in Table 3), namely: tropical, temperate and boreal. The temperate and the boreal biome were further subdivided into either cool $\left(<22{ }^{\circ} \mathrm{C}\right)$ or warm $\left(=>22^{\circ} \mathrm{C}\right)$ types to distinguish between $\mathrm{C} 3$ or $\mathrm{C} 4$ photosynthesis in the former, and temperate needleleaf and broadleaf trees in the latter (based on their PFT temperature establishment thresholds in Table 2). While C4 grasses can establish at cooler temperatures (i.e., the LPJ model uses a temperature of $15^{\circ} \mathrm{C}$, Table 2), this temperature threshold $\left(22^{\circ} \mathrm{C}\right)$ has been shown in prior studies to be a critical "crossover" temperature for $\mathrm{C} 3$ and $\mathrm{C} 4$ adaptations (Collatz et al., 1998).

Each of the 4 reclassified phenology type datasets were then merged with the climate zones to produce the final PFT classification at the spatial resolution of the original land cover data following the assembly rules in Table 7. Some exceptions were made to account for the full combination of phenology and climate zone possibilities. For example, because there are few to no deciduous needleleaf PFTs observed in tropical and temperate ecosystems, this phenology type was treated as tropical broadleaf raingreen (deciduous) or temperate broadleaf summergreen PFT. Natural and managed grasslands were split into the $\mathrm{C} 3$ and $\mathrm{C} 4$ photosynthetic pathways according to temperature thresholds that defined tropical versus temperate, and cool versus warm temperate biomes from the Köppen-Geiger data. This approach may underestimate $\mathrm{C} 3 / \mathrm{C} 4$ grass mixtures or $\mathrm{C} 4$ summer crops (i.e., maize) that might be planted in cooler regions (Ramankutty and Foley, 1998).

The PFT classifications were aggregated to a spatial resolution of $0.5^{\circ}$ by summing the area of each PFT class within the corresponding $0.5^{\circ}$ cell (16 classes, Table 7) and dividing by the grid cell area. A spatial resolution of $0.5^{\circ}$ was chosen for this study because most models in the ESM community use climate and other ancillary driver (e.g., soil type) data at this resolution, or greater (Zobler, 1986; New et al., 2002). The aggregation of PFT fractions can also be carried out at finer resolution, but at smaller window sizes the estimates of fractional PFT coverage may become more sensitive to the selection of probability distribution. Each of the four PFT fractional abundance files were filtered with a global land/water mask, which was derived from a global soils database (Zobler, 1986). This ensured that the terrestrial surface area and land/ocean boundaries were equal between datasets.

\subsection{Measuring PFT agreement}

We analyzed the agreement between PFT fractional abundance (and re-groupings of PFTs by various traits) with a beta (ß) diversity metric (mean Euclidean distance) calculated for each grid cell. Euclidean distance is a measure of dissimilarity between groups with multiple members (Legendre et al., 2005) and is commonly used to summarize landscape species diversity from multiple sampling plots (Whittaker, 1972). In our case, the "plots" were the grid cells which contained the fractional PFT abundances contained from the different classification datasets. This analysis had two objectives; the first was to assess, geographically, where regions of high uncertainty in PFT abundance may exist, the second was to help evaluate the methods for the reclassification of legends, especially for the mixed vegetation categories.

The beta diversity metric was calculated for each grid cell for each of the four datasets, for the standard PFT classification, and for three re-groupings based on PFT traits. These regroupings were 1 . Phenology type (total evergreen versus total deciduous fraction), 2. Physiognomy (total woody versus total herbaceous fraction), and 3. Management status (natural grass versus managed grass). Equation (1) presents the variables used for calculating the Euclidean distance, the mean of which, we consider to represent beta diversity, B. For every grid cell $c$, the Euclidean distance, $D$ was calculated between every combination of classifications, $N$ $(1 \ldots 4)$ composed of 10 PFTs $(I=10)$ and their corresponding fractional abundance $A$ for the different classifications ( $j$ and $k$ ).

$\beta_{\mathrm{c}}=\bar{D}_{c}=\frac{\sum_{n=1}^{N}\left[\sum_{i=1}^{I}\left(A_{i, j, c}-A_{i, k, c}\right)^{2}\right]^{0.5}}{N}$ 
Table 6. Modis collection 4 and 5 legend (IGBP) and corresponding DGVM phenology class (from Table 2). For mixed phenology cells, it was assumed that any phenology type could be found, these were determined randomly using a uniform distribution.

\begin{tabular}{lll}
\hline MODIS ID & MODIS description & DGVM phenology class \\
\hline 0 & Water & $100 \%$ Water \\
1 & Evergreen Needleleaf Forest & $100 \% \mathrm{NeEv}$ \\
2 & Evergreen Broadleaf Forest & $100 \% \mathrm{BrEv}$ \\
3 & Deciduous Needleleaf Forest & $100 \% \mathrm{NeDe}$ \\
4 & Deciduous Broadleaf Forest & $100 \% \mathrm{BrDe}$ \\
5 & Mixed Forests & $25 \% \mathrm{BrEv}, \mathrm{BrDe}, \mathrm{NeEv}, \mathrm{NeDe}$ \\
6 & Closed Shrublands & $10 \%, \mathrm{BrEv}, \mathrm{BrDe}, 30 \% \mathrm{NeEv}, 10 \%$ NeDe, $40 \%$ NatGrass \\
7 & Open Shrublands & $10 \% \mathrm{BrEv}, \mathrm{BrDe}, \mathrm{NeDe}, \mathrm{NeEv}, 20 \%$ NatGrass, $40 \%$ Bare \\
8 & Woody Savannas & $20 \%, \mathrm{BrEv}, 10 \% \mathrm{BrDe}, 20 \%$ NeEv, $50 \%$ NatGrass \\
9 & Savannas & $10 \%$, BrEv, 20\% NeEv, $70 \%$ NatGrass \\
10 & Grasslands & $100 \%$ NatGrass \\
11 & Permanent Wetlands & $20 \%$ BrEv, BrDe, NeEv, NeDe, NatGrass \\
12 & Croplands & $100 \%$ ManGrass \\
13 & Urban and Built-Up & $100 \%$ Urban \\
14 & Cropland/Natural Vegetation Mosaic & $8 \%$ BrEv, BrDe, NeEv, NeDe, NatGrass, ManGrass \\
15 & Snow and Ice & $100 \%$ Bare \\
16 & Barren or Sparsely Vegetated (<10\% veg. cover) & $10 \%$ NatGrass, $90 \%$ Bare \\
17 & (IGBP Water Bodies, recoded to 0 for MODIS Land Product consistency.) & $100 \%$ Water \\
254 & Unclassified & $100 \%$ No data \\
255 & Fill Value & $100 \%$ No data \\
\hline
\end{tabular}

Table 7. Final merging rules for phenology and climate zone, and legend for final PFT map (including non-PFT categories).

\begin{tabular}{|c|c|c|c|}
\hline Biome & Phenology & PFT Category & Data Band \\
\hline Tropical & Broadleaf evergreen & Tropical Broadleaf Evergreen & 1 \\
\hline Tropical & Broadleaf deciduous Needleleaf deciduous & Tropical Broadleaf Raingreen & 2 \\
\hline Tropical Temperate (warm) Temperate (cool) Boreal (warm) & Needleaf evergreen & Temperate Needleleaf Evergreen & 3 \\
\hline Temperate (warm) Temperate (cool) Boreal (warm) Boreal (cool) & Broadleaf evergreen & Temperate Broadleaf Evergreen & 4 \\
\hline Temperate (cool) Temperate (warm) Boreal (warm) & Broadleaf deciduous Needleleaf deciduous & Temperate Broadleaf Summergreen & 5 \\
\hline Boreal (cool) & Needleleaf evergreen & Boreal Needleleaf Evergreen & 6 \\
\hline Temperate (cool) Boreal (cool) & Needleleaf deciduous & Boreal Needleleaf Deciduous & 7 \\
\hline Boreal (cool) & Broadleaf deciduous & Boreal Broadleaf Summergreen & 8 \\
\hline Temperate (cool) Boreal (warm) Boreal (cool) & Natural Grass & Natural grassland C3 & 9 \\
\hline Tropical Temperate (warm) & Natural Grass & Natural grassland C4 & 10 \\
\hline Temperate (cool) Boreal (warm) Boreal (cool) & Managed Grass & Managed grassland C3 & 11 \\
\hline Tropical Temperate (warm) & Managed Grass & Managed grassland $\mathrm{C} 4$ & 12 \\
\hline \multirow{4}{*}{ Non-vegetated } & & Barren/Bare & 13 \\
\hline & Water & 14 & \\
\hline & Urban & 15 & \\
\hline & No Data & 16 & \\
\hline
\end{tabular}

The mean Euclidean distance (beta diversity) between groups $\left(\bar{D}_{c}\right)$ was calculated as the mean of the diagonals from the resulting matrix to represent overall dissimilarity (Legendre et al., 2005; Whittaker, 1972). The variance of the Euclidean distance matrix was also calculated using the same approach, but taking the variance of the matrix diagonals rather than the mean. The two approaches were used to aggregate the distance matrix into a single index as recommended by Legendre et al. (2005). B was plotted as both geographic maps and as latitudinal summaries to explore the spatial patterns of uncertainty for each grouping.

An ordination analysis was conducted for four individual grid cells representative of major biomes (temperate, tropical, boreal, and desert) to investigate the similarity between PFT products and to display the main gradients partitioning them. The PFT products included those developed in this study, the existing products described in the Introduction for Orchidee and CLM, and the results from a DGVM simulation from LPJmL (described below). Non-metric multidimensional scaling (NMDS) was chosen (using a Euclidean distance matrix); this ordination method is less sensitive to non-linear relationships among variables.

\subsection{Prescribing PFT data to a dynamic global vegetation model}

PFT fractions were prescribed to the LPJmL DGVM, an ecosystem model that simulates global biogeography and biogeochemistry via coupled water-carbon cycling and vegetation dynamics (Sitch et al., 2003). Bioclimatic thresholds 
Table 8. Global plant functional type and non-vegetated cover $(\%)$ for land surface.

\begin{tabular}{llllll}
\hline PFT & GLC2000 & Globcover & Modis C004 & Modis C005 & StDev \\
\hline Tropical Broadleaf Evergreen & 7.97 & 6 & 11.47 & 11.13 & 2.62 \\
Tropical Broadleaf Raingreen & 7.52 & 8.96 & 2.71 & 3.15 & 3.13 \\
Temperate Needleleaf Evergreen & 3.68 & 5.68 & 5.32 & 5.6 & 0.94 \\
Temperate Broadleaf Evergreen & 2.86 & 3.3 & 5.24 & 5.22 & 1.25 \\
Temperate Broadleaf Summergreen & 5.51 & 5.38 & 3.08 & 3.22 & 1.33 \\
Boreal Needleleaf Evergreen & 5.78 & 5.24 & 5.77 & 5.62 & 0.25 \\
Boreal Needleleaf Deciduous & 3.87 & 4.05 & 2.45 & 3.78 & 0.73 \\
Boreal Broadleaf Summergreen & 4.05 & 3.09 & 2.39 & 2.47 & 0.77 \\
Natural grassland C3 & 7.45 & 7.7 & 7.56 & 8.04 & 0.26 \\
Natural grassland C4 & 13.87 & 11.21 & 17.99 & 19.13 & 3.67 \\
Managed grassland C3 & 5.01 & 3.92 & 5.26 & 5.14 & 0.62 \\
Managed grassland C4 & 8.56 & 8.83 & 4.87 & 4.95 & 2.19 \\
Unvegetated (ice/barren, urban, water, no & 23.88 & 26.62 & 25.87 & 22.55 & 1.80 \\
data) & & & & & \\
\hline
\end{tabular}
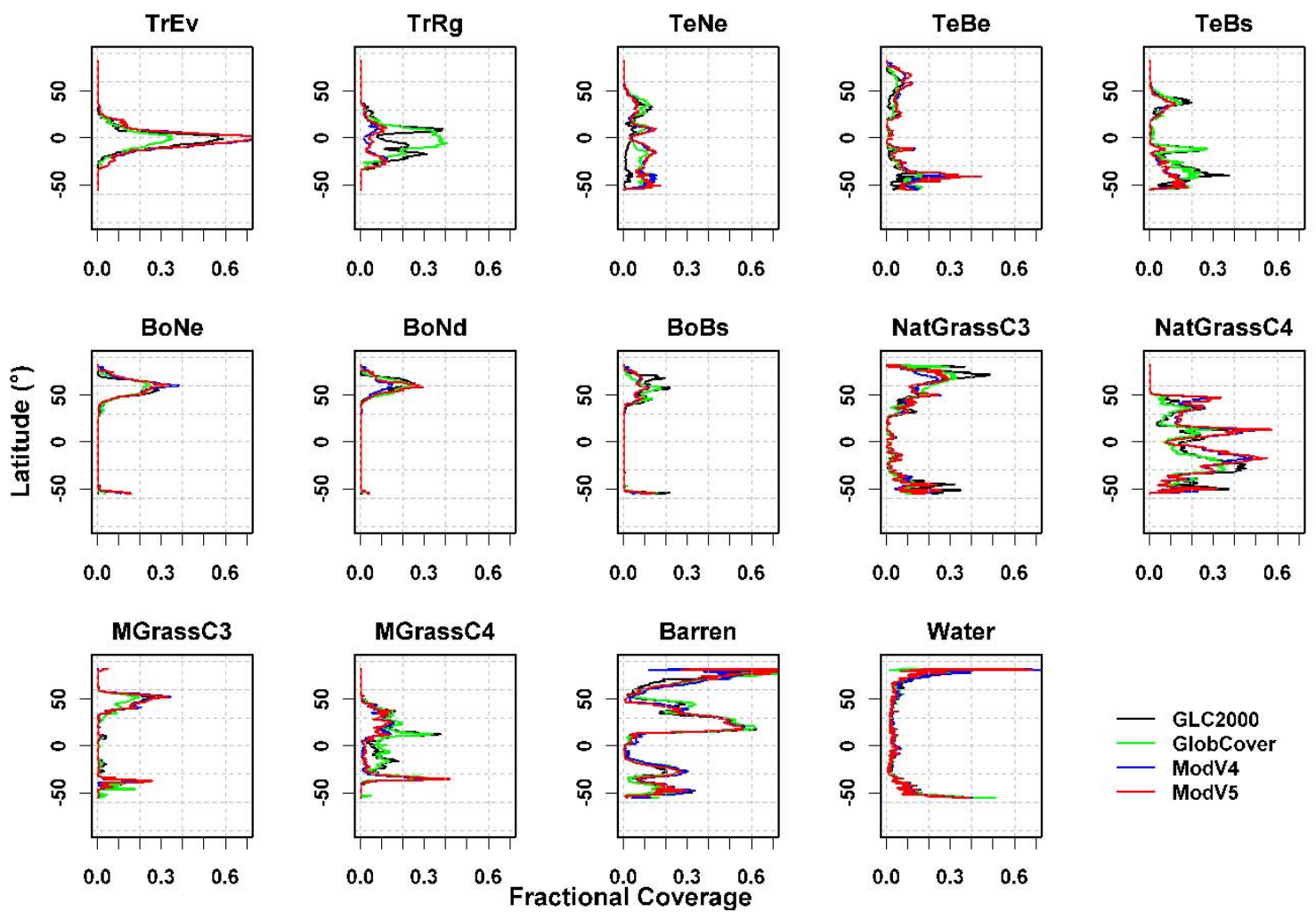

Fig. 2. The latitudinal distribution of the plant functional types for each land-cover dataset. The PFT acronyms correspond to those in Table 2.

were removed to allow the establishment of PFTs wherever they were prescribed from the external datasets. In the LPJmL model, diagnostic PFT fractions replaced the variable for maximum annual fraction of photosynthetic absorbed radiation (FPAR) while not modifying the vegetation dynamics or physiology modules. Monthly climate data (precipitation, temperature, cloud cover, and wet days) and annual $\mathrm{CO}_{2}$ concentrations were prescribed from the Climatic Research Unit TS3.0 dataset (Mitchell and Jones, 2005) and the Carbon Dioxide Information Analysis Center (CDIAC). Following a 1000-yr spin up to equilibrate vegetation and carbon pools, a transient simulation, including the effects of prognostic fire 

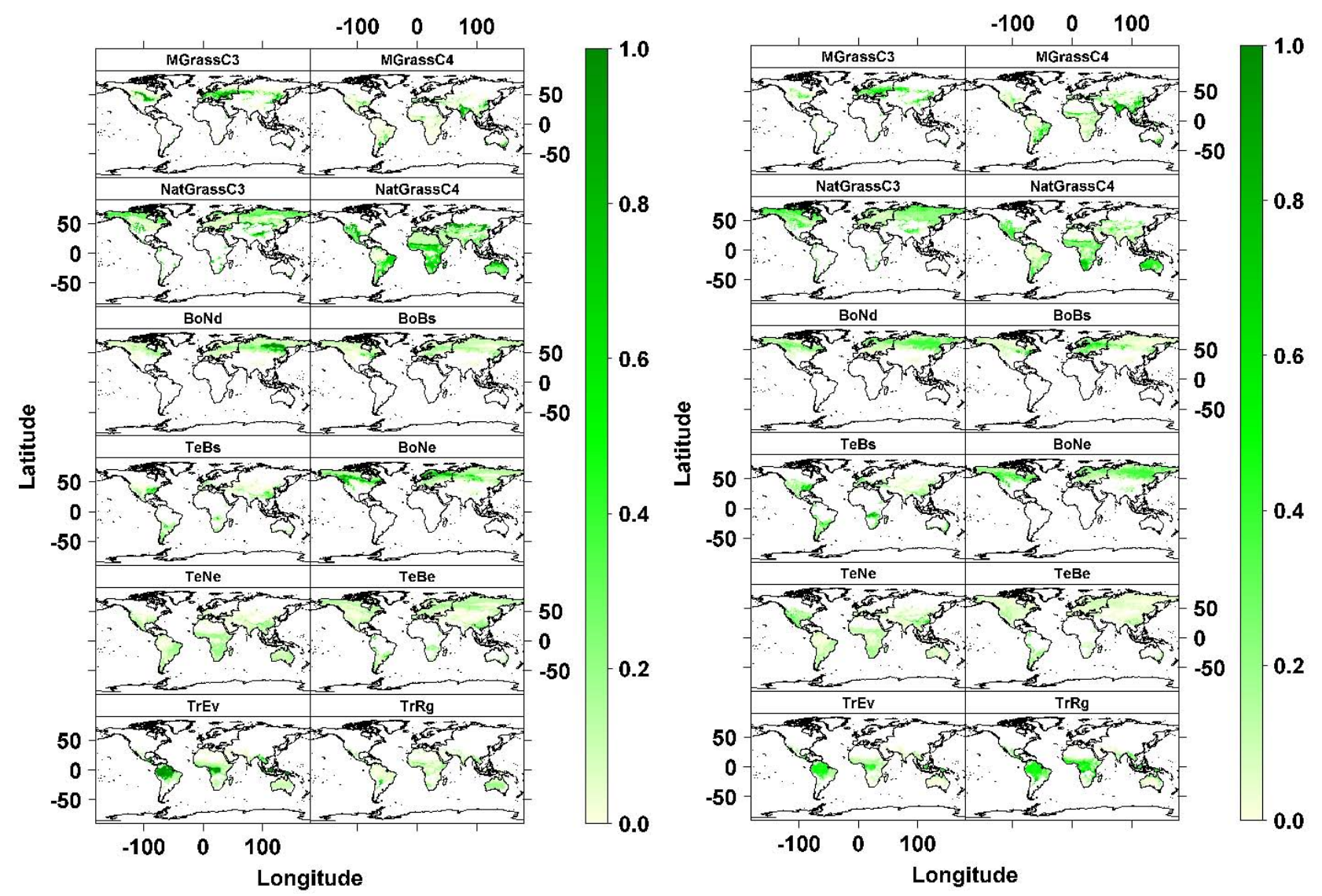

Fig. 3. Map of the PFT fractions (at 0.5 degrees resolution) from (a) Modis C005 land-cover inputs using the IGBP legend, and (b) GlobCover land-cover inputs using the LCCS legend. The PFT acronyms correspond to those in Table 2.

(Thonicke et al., 2001), was initiated beginning in 1901 and ending in 2005. Managed grasslands were treated as in Bondeau et al. (2007), with harvest occurring repeatedly during the year when peak leaf area index (LAI) was reached. Annual GPP and transpiration (from 1956-2005) were regressed with mean annual temperature, total annual photosynthetic active radiation (PAR), and total annual precipitation, from the same time period, to calculate partial correlation coefficients used to interpret the sensitivity of the biogeochemical fluxes to climate.

\section{Results}

\subsection{Uncertainty in global PFT fractions}

At the global scale, managed and unmanaged grassland PFTs, which includes croplands and pasture, were most abundant in terms of percent land area $(\sim 30 \%)$, followed by tropical $(\sim 15 \%)$, boreal $(\sim 12 \%)$, and temperate PFTs $(\sim 11 \%)$ (Table 8). Classification agreement (Table 8$)$ was lowest (for globally averaged values) for $\mathrm{C} 4$ grasses, especially for natural $\mathrm{C} 4$ grasslands. Tropical raingreen $(\mathrm{TrRg})$ and tropical evergreen (TrEv) PFT fractional coverage also had high uncertainty, both in savanna regions, and in the Amazon and Congo River Basins (acronyms explained in Table 2). The lowest uncertainty was found for the boreal needleleaf PFT (BoNe) and natural/managed $\mathrm{C} 3$ grasslands.

The spatial uncertainty of PFT agreement was low in the boreal biome, increasing to some extent in the temperate biome, and highest in the tropics (Fig. 2). The disagreement between land-cover datasets was greatest for deciduous PFT phenology types compared to evergreen PFTs, which was especially important in the tropics where the GlobCover dataset categorized the Amazon and Congo River Basins as mixedleaf or seasonal forest (in comparison to the "evergreen" phenology type for the other datasets). Managed and natural C3 grasslands showed high dissimilarity in the mid-western United States mostly because GlobCover had low fractions of managed grassland in this region (Fig. 2; MGrassC3 low abundance between $40-50^{\circ} \mathrm{N}$ ). $\mathrm{C} 4$ grasslands (both natural and managed) showed high dissimilarity because of differences related to distinguishing natural versus managed grassland, and because of differences in how the land-cover datasets treated barren/dry areas. For example, much of 

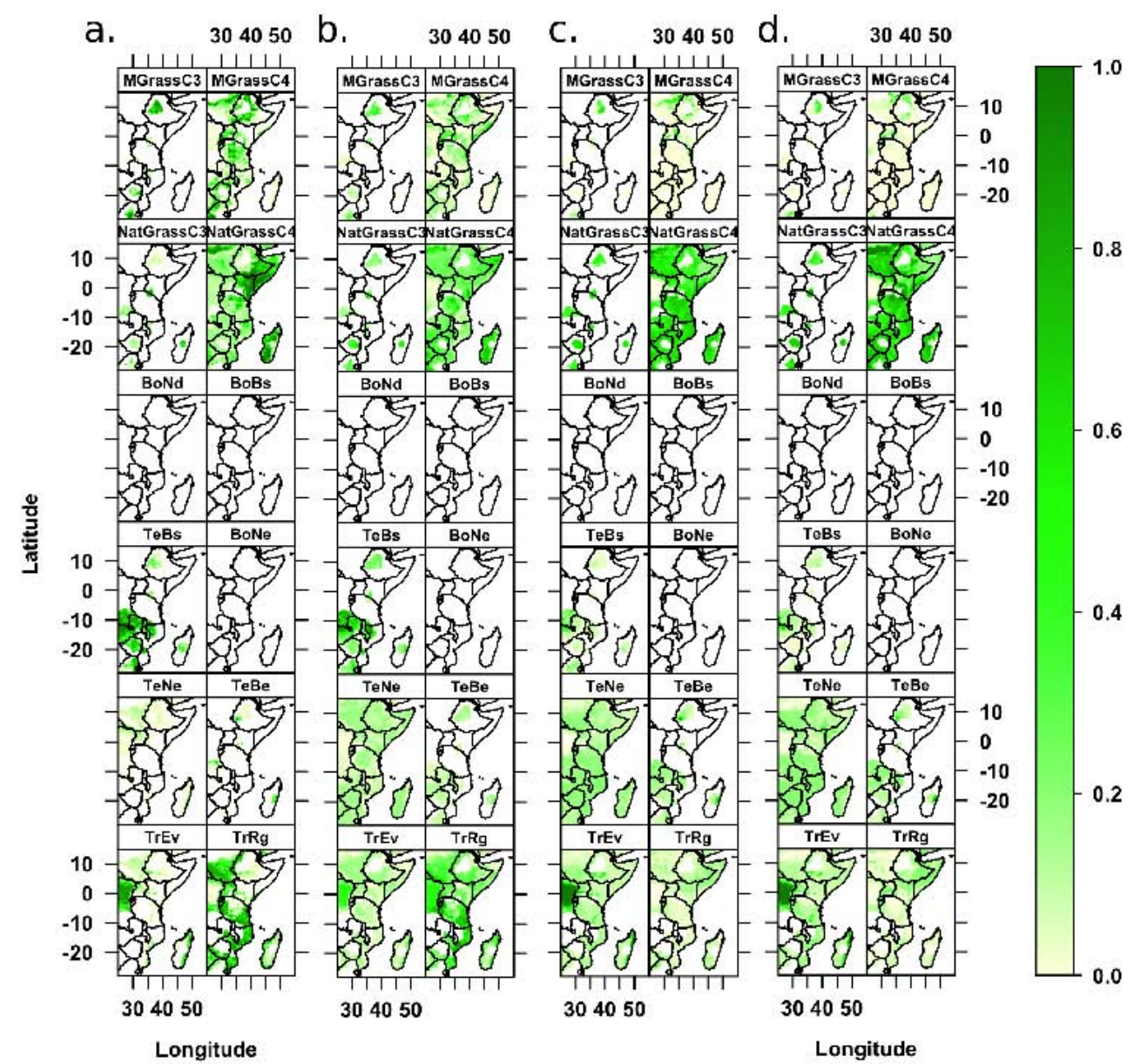

Fig. 4. Close-up illustration of PFT fractions for (a) GLC2000, (b) GlobCover, (c) Modis C004 and (d) Modis C005 for Eastern Africa where fine-scale topographic features and their effects on climate zones are apparent.

interior Australia was classified as "open shrublands" by the IGBP MODIS legend (Fig. 3a; higher abundance of TrEv and TrRg compared to Fig. 3b). Our reclassification for the IGBP legend assigned $40 \%$ of this class to woody PFTs, $20 \%$ to grass PFTs and $40 \%$ to barren. In comparison, the LCCS legend reclassifies part of this region as "sparse vegetation", which we reclassified as $40 \%$ grass PFT and $60 \%$ bare, consistent with the supporting documentation for LCCS (Fig. 3b; lower abundance of TrEv and TrRg). The IGBP "open shrubland" category also includes tundra and permafrost biomes (in addition to the warmer arid regions). Herbaceous cover may be higher in these cooler regions than in "open shrublands" of warm regions (Fig. 3b; NatGrassC3 replaces by BoNe), which suggests that further refinement of shrubland categories could improve differences between land-cover products.

Spatial resolution and the detail of land-cover categories had important effects in intensively managed landscapes. For example, in the Southeastern United States, the GlobCover dataset $(0.3 \mathrm{~km})$ and LCCS legend (22 classes) bet- ter distinguished secondary succession vegetation (Fig. 3b; higher abundance of TeNe) (i.e., pine forests from agricultural abandonment, Christensen and Peet, 1984). Climatic differences across small gradients were generally detected by the Köppen-Geiger classification, despite elevation not being included in the interpolation process. These topographic features were apparent in the north-south divide along the island of Madagascar (Fig. 4a-d; NatGrassC4 versus TrRg), along the Andes, separating the Amazon rainforests from highelevation grasslands, as well as in Ethiopia, where the effects of the highland rift-valley corresponded to $\mathrm{C} 3$ grasslands in a region mostly surrounded by $\mathrm{C} 4$ climate zones (Fig. $4 \mathrm{a}-\mathrm{d}$; NatGrassC3).

GlobCover and GLC2000 detected higher fractions, $\sim 12-$ $13 \%$, of managed grasslands globally. Compared to the MODIS products, this estimate is slightly less than $\sim 14 \%$ for cropland area found in previous studies scaled to FAO country statistics (Ramankutty and Foley, 1998; Klein Goldewijk et al., 2007). GlobCover also distinguished alpine vegetation communities in more detail (compared to GLC2000 


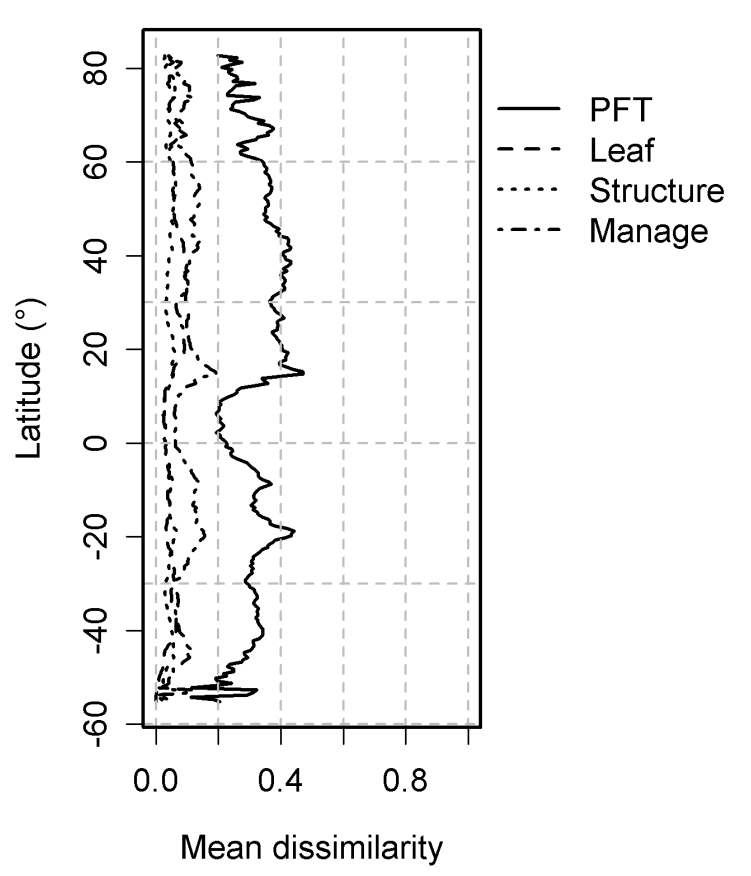

Fig. 5. Latitudinal distributions of mean dissimilarity for the 3 different grouping of PFT traits and for all PFTs (described in Methods: Measuring PFT agreement).

and MODIS) for the European Alps. C4 abundance was higher than in Still et al. (2003) who found that globally, C4 vegetation compose $\sim 15 \%$ of terrestrial vegetation (whereas the estimates presented here are closer to $\sim 22 \%$, Table 8 ). The higher estimates for $\mathrm{C} 4$ grass abundance are due, in part, to differences in the IGBP "grasslands" and LCCS "sparsely vegetated" categories, which corresponded to the LCCS "sparse vegetation" or "barren" categories (Fig. 3a and b; see MGrassC4). For IGBP, "grasslands" were reclassified to $100 \%$ grass cover (Table 6), but for LCCS "sparse vegetation," only $40 \%$ grass cover (Table 5 ).

The disagreement between PFT trait-groups (see categories described in Methods: Measuring PFT agreement), was highest in the tropics (Fig. $5 ; 20^{\circ} \mathrm{N}$ to $20^{\circ} \mathrm{S}$ ) and for a "hotspot" in the mid-western United States (Fig. 5; 35$55^{\circ} \mathrm{N}$ ) resulting from managed versus natural grassland classification. Phenology-type disagreement was also high in the tropics, but in general, structural (physiognomy) observations appear to have high agreement (Fig. 5). In the northern temperate zone, grasslands were more consistently classified as managed, with the exception of mid-western USA, where GlobCover underestimated cropland fraction compared to GLC2000 and MODIS (Fig. 2; MGrassC3). Tropical savannas and warm-climate croplands emerged as bands of disagreement, because of differences between the IGBP and LCCS classification for natural and managed $\mathrm{C} 4$ grassland and shrubland categories. A notable region of high uncertainty was the Karakum desert in Central Asia which was classified as "barren" or "sparse vegetation" in LCCS and as "grassland" in IGBP leading to large differences in estimated PFT fractions (Fig. 6).

\subsection{Land cover and the uncertainty of fluxes to climate}

In diagnostic mode (with PFT distributions prescribed), global GPP ranged from 130.9 to $134.9 \mathrm{PgCa}^{-1}$ (averaged over 1996-2005) and transpiration ranged from 43200 to $44600 \mathrm{H}_{2} \mathrm{O} \mathrm{km}^{3} \mathrm{a}^{-1}$. These global values were similar to the prognostic (dynamic vegetation) simulation, using the Hyde dataset for managed grasslands (Klein Goldewijk and Batjes, 1997), which produced values of $131.0 \mathrm{PgC} \mathrm{a}^{-1}$ and 39000 $\mathrm{H}_{2} \mathrm{O} \mathrm{km}^{3} \mathrm{a}^{-1}$. All estimates are close to previous analyses of global carbon Beer et al., 2010) and water fluxes (Gerten et al., 2005). GPP and transpiration sensitivity to climate followed similar patterns observed in previous studies $(\mathrm{Ne}-$ mani et al., 2003), with temperature important in northern latitudes, radiation more limiting in the wet tropics, and precipitation a dominant feature globally (Fig. 8a). As in Beer et al. 2010), precipitation was the most important global climate variable controlling GPP (65-70\%) and transpiration $(58-63 \%)$. The range of uncertainty was similar for either GPP or transpiration sensitivity to climate; with agricultural regions in mid-western USA and Europe, and arid regions in Australia and S. Africa showing high uncertainty in the sensitivity of GPP to precipitation (Fig. 8b). In agricultural regions, the lower fractional coverage of croplands in the GlobCover product led to higher grassland LAI (because of no harvesting), causing higher sensitivity (or correlation coefficient) to precipitation. In semi-arid regions, the MODIS products led to higher GPP sensitivity to precipitation (Figure 8) because of a higher abundance of woody species (with deeper rooting strategies) unable to compete efficiently for minimal rainfall with grasses that had shallow rooting strategies.

\section{Discussion}

\subsection{PFT datasets and themes for improvement}

PFT datasets must remain consistent with available satellite products used for data assimilation (i.e., LAI, FPAR or biomass assimilation) and account for recent changes associated with land-use dynamics. Here, we have evaluated an approach for establishing a series of PFT datasets for use within Earth System Models and DGVMs, and explored patterns of disagreement and their propagated effects to land-surface process uncertainty. To date, available PFT datasets for ESM models have been limited to single satellite sensors and partly outdated land-cover data (i.e., 1992/1993 AVHRR data). The approach used in this study increases the resources available for evaluating ensemble uncertainties introduced from landsurface state variables and we discuss possible opportunities for refining classification methodologies. 


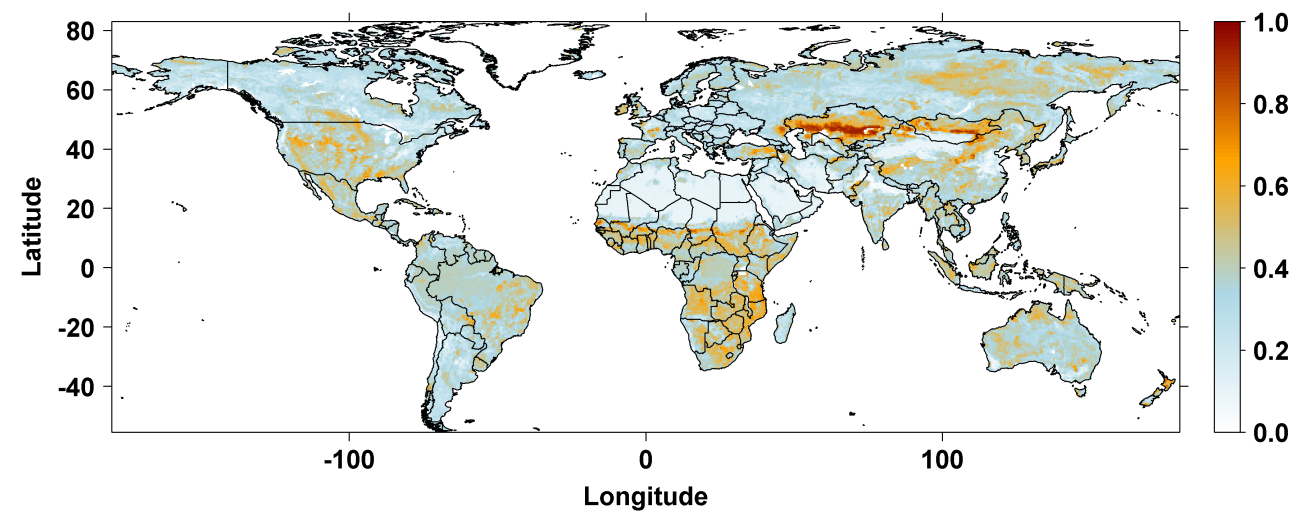

Fig. 6. TMap of mean fractional dissimilarity ( 0 is complete agreement and 1 is complete disagreement) considering all PFTs using the beta-diversity metric (Eq. 1). Representative grid cells shown in Fig. 7 illustrate the main patterns of clustering and spread of the existing products in comparison to the new PFT products presented here.
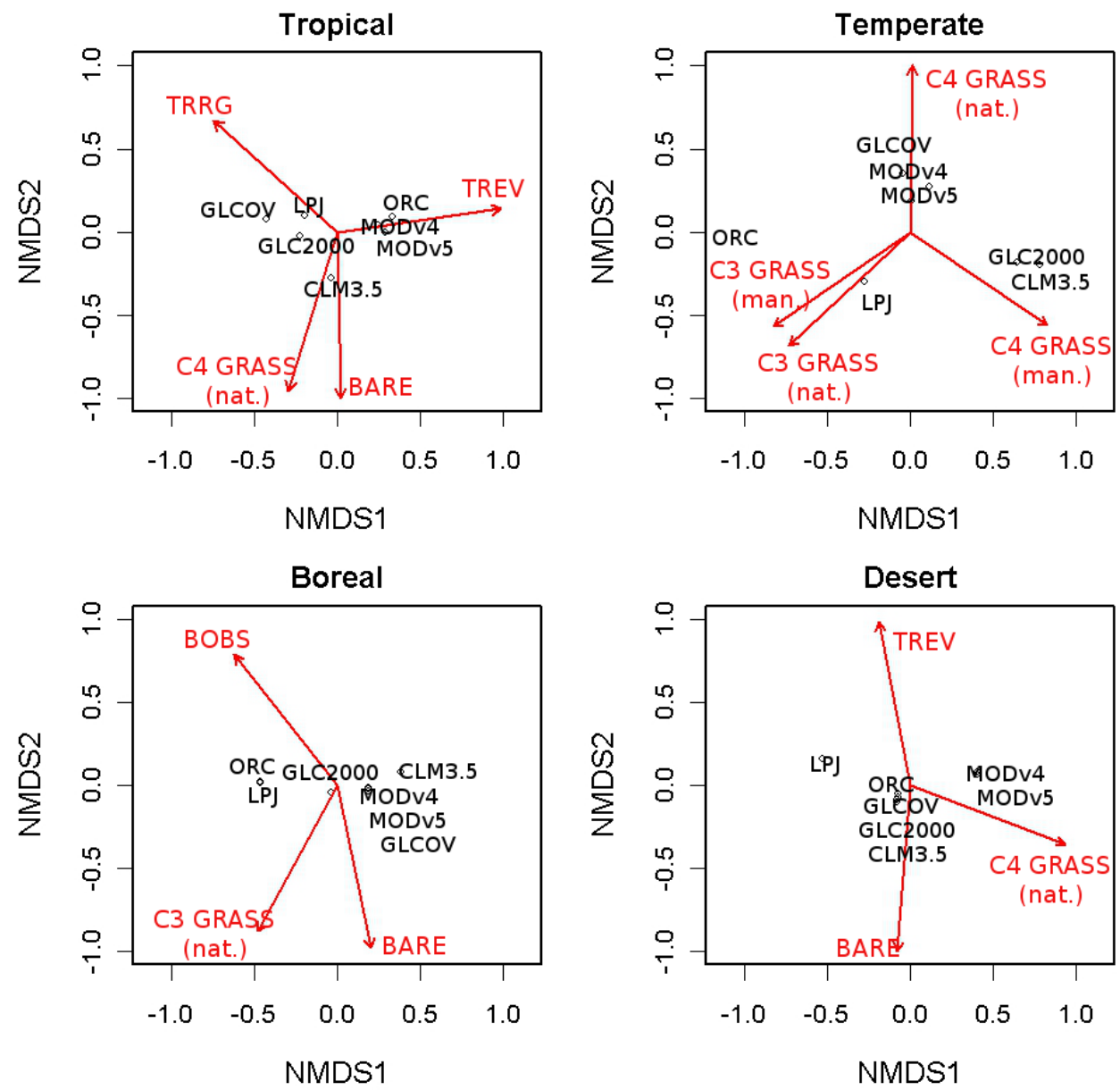

Fig. 7. Comparison of the 4 new PFT products to one another and the existing products based on older datasets. The NMDS ordination shows the degree of differences and clustering of the products (black names) and the major PFT gradients $(p<0.05)$ that explain the differences in the gradients (red names). The LPJ product is the PFT composition from a fully dynamic vegetation simulation, described in the Methods. 

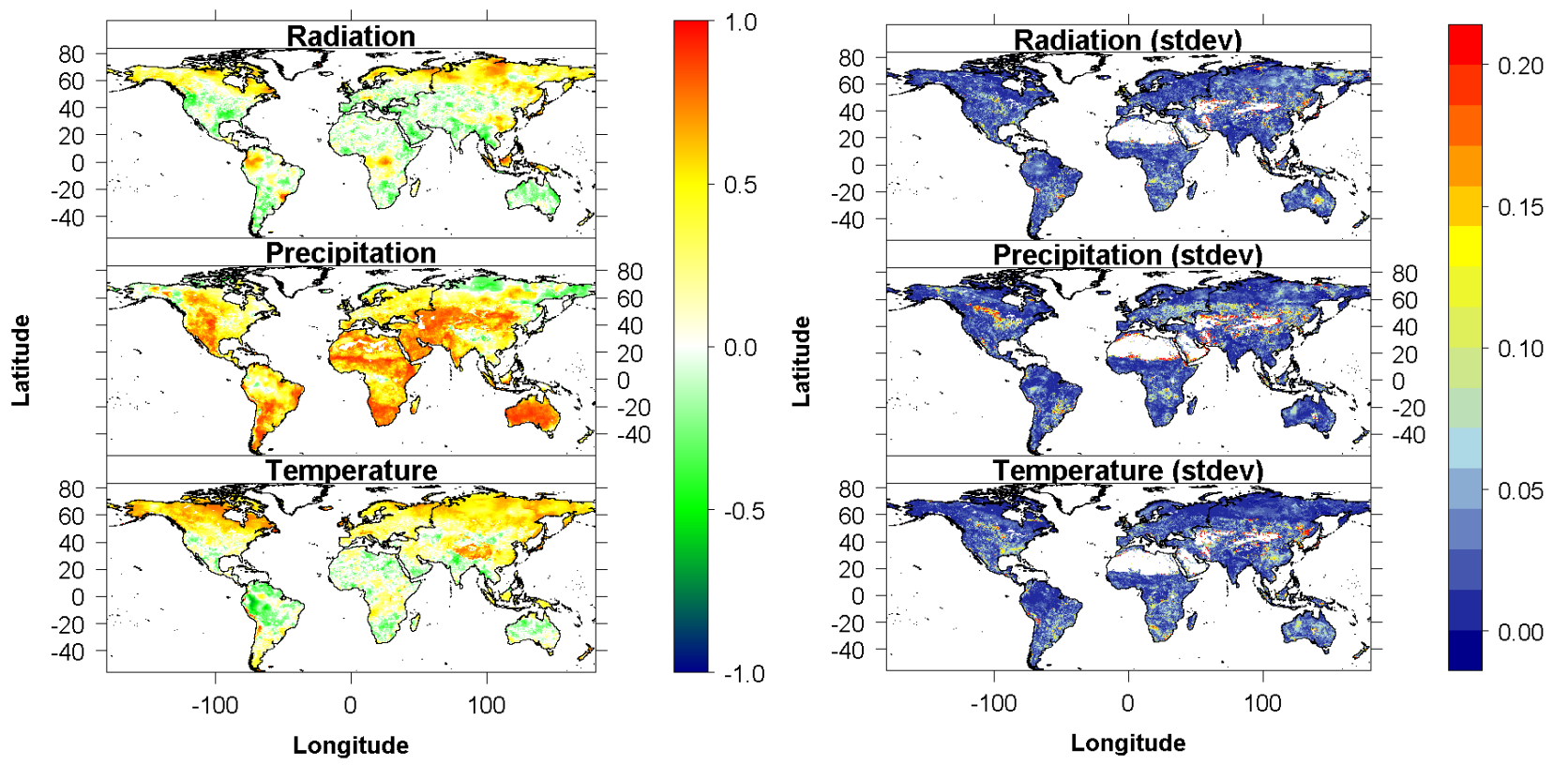

Fig. 8. (a) Partial correlation coefficients (PCC) for modeled GPP to radiation, precipitation, and temperature variable for the MODIS C005 $\mathrm{PFT}$ product (b) standard deviation of the PCC for all four land-cover simulations.

The main areas of disagreement were found in regions of intensive land management or in regions where accurate spectral discrimination between similar land cover, but different land use, caused classification problems (e.g., cropland and natural grassland). High-disagreement was also found in warm/cool arid regions where land-cover categories were either too broadly defined or because different legend types had conflicting tree-cover thresholds to define forest vegetation. Previous studies have also observed that dryland systems, which include heterogeneous mixtures of grasslands, croplands and savanna shrublands, feature as prominent zones of disagreement (Giri et al., 2005; Herold et al., 2008; Fritz and See, 2008). Our results confirm that this disagreement scales to PFT groupings and contributes a large part of the land-surface process uncertainty for GPP and transpiration sensitivity to climate (Fig. 9).

Much of this disagreement results from differences in the classification for forest land; the LCCS definition for forest is an area with more than $15 \%$ tree cover, whereas IGBP uses a $60 \%$ tree-cover threshold. Consequently, the MODIS product has a much larger fraction of (non-forest) shrubland and savanna systems, which are categorized as various "open" or "closed" forest types in GLC2000 and GLOBCOVER, Tables 4 and 6 . Such problems stem from defining forest structure from forest cover, which may be overcome with new developments in satellite-based lidar, which can successfully provide measurements of tree height and vertical structure at global extents (Lefsky, 2010). Overlap of cool or warm aridland categories (i.e., grassland, shrubland, barren), also introduced error in deserts and tundra regions, where broadly defined categories could be improved by including climate information. Arid-regions have large global coverage and recent work suggests that these ecosystems have a significant influence on global biogeochemistry and the climate system itself via biophysical properties (Rotenberg and Yakir, 2010), hence a better understanding of their distribution could contribute to reducing uncertainty of global climate processes.

The humid tropics remain an additional challenge for biogeochemical modeling, in part, due to a need to better understand basic ecophysiological processes (Baker et al., 2008), but also because of data collection limitations. Remote sensing data for tropical vegetation must first be processed to remove seasonal cloud cover and aerosol contamination (Poulter and Cramer, 2009; Kobayashi and Dye, 2005), and also account for the rapid pace and complex spatial patterns arising from deforestation and fire (Morton et al., 2006). In our study, these measurement problems contributed to land-cover uncertainty in the classification of natural versus managed grasslands in southeastern Brazil, and in the classification of the phenology type for the wet-tropical forests. Quantifying the degree of seasonal tropical forest phenology is a longstanding problem and studies disagree at the level to which these forests shed their leaves during the dry season (Samanta et al., 2010; Saleska et al., 2007). Despite the disagreement among tropical PFTs, the uncertainty in GPP and transpiration sensitivity to climate was relatively low (Figs. 8b and Fig. 9, Tropical America and S. Africa regions). This was because of similarities in the ecological functioning of the modeled raingreen and evergreen PFTs in non-water stressed environments (see Poulter et al., 2009). 

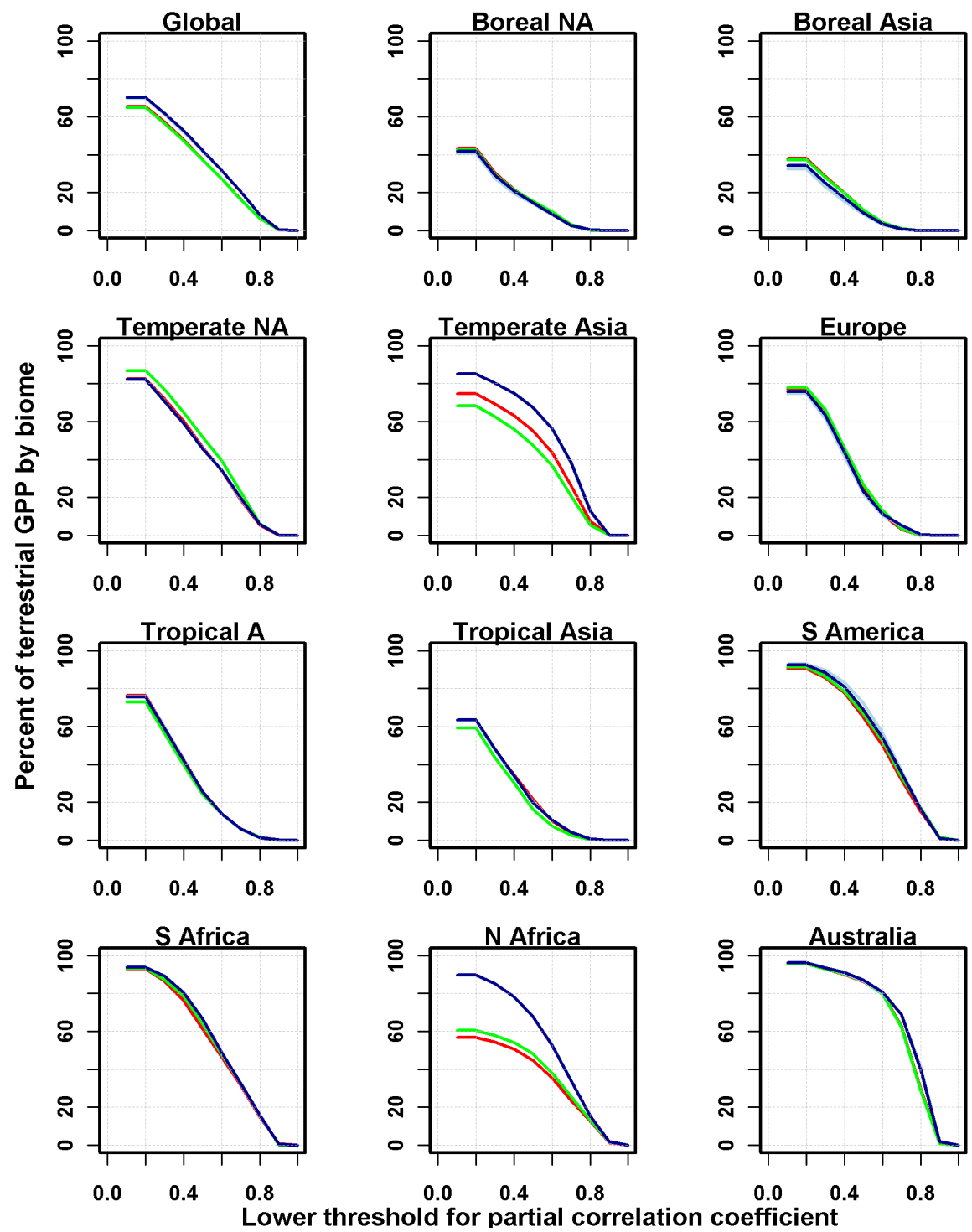

Fig. 9. Cumulative partial correlation between GPP and precipitation using the same approach as described in Beer et al. (2010). Zones correspond to TRANSCOM 3 biome regions (Gurney et al., 2003), and legend colors red for GLC2000, green for GlobCover, light blue for Modis v4, and dark blue for Modis v5.

Our analysis suggests that the PFT uncertainties could be reduced by using land-cover data based on high to moderatespatial resolution and a larger number of legend categories (as in GlobCover). For example, the more detailed LCCS legend was better able to handle dry-land classifications than the coarser IGBP legend and GlobCover appears to classify heterogeneous landscapes well. Future versions of MODIS land-cover data are expected to include the LCCS legend (Friedl et al., 2010), which in addition, should further reduce errors from user-based reclassification necessary for landcover product comparisons.

\subsection{Application with Earth System Models}

Developments in ESM models will likely focus on including a higher diversity of PFT and crop functional types and entirely new approaches that include adaptive, rather than fixed, traits for PFT parameters (Scheiter and Higgins, 2009). The number of PFT types is not restricted to those presented in our study and the next generation of DGVMs, with higher-functional diversity, will be better prepared to evaluate ecosystem resilience and stability hypotheses related to global change. However, increasing PFT diversity requires detecting life history traits (i.e., growth form and dispersal rates) not readily observable at global scales or from space (Ustin and Gamon, 2010). The utility of the PFT 
approach for hypothesis testing and linkage to remote sensing will remain important. Finer resolution categories of crop types has been shown to be important for global biogeochemical cycling (Bondeau et al., 2007) but crop types or crop cover (or pasture) is not easily distinguished in the global land-cover datasets, highlighting the importance of integrated land-cover mapping approaches. Managed grassland categories can be subdivided using regional statistics on crop use, similar to methods described by Ramankutty et al. (1998), but many earth system models are at the early stages of incorporating crop functional types.

By forcing LPJmL with diagnostic PFT fractions we were able to illustrate the utility of ensembles of land-cover approaches and the application of diagnostic datasets. Interestingly, global estimates of GPP and ET were similar, regardless of land cover, confirming studies conducted at continental scales (Jung et al., 2007). However, we show that there are large regional differences, $20-30 \%$, in the sensitivity of biogeochemical fluxes to climate that are directly linked to land-cover uncertainty. High-PFT uncertainty did not always correspond to high biogeochemical cycling uncertainty (e.g., wet tropics), illustrating that propagated errors may differ from the initial condition agreement and that the choice of evaluation metric is important. These PFT datasets have applications beyond ESM modeling and can be integrated with bottom-up studies, include accounting methods for evaluating carbon stocks (Kindermann et al., 2008), or as base-maps that can inform biodiversity-patterns related to biogeography (Loucks et al., 2008).

Acknowledgements. B. Poulter acknowledges funding from an FP7 Marie Curie Incoming International Fellowship (Grant Number 220546). NE Zimmermann and H Lischke acknowledge support through the FP6 and FP7 projects ECOCHANGE (GOCE-CT2007-036866) and MOTIVE (ENV-CT-2009-226544). E Hodson acknowledges support from the MAIOLICA Project. The authors are grateful for the development and distribution of the remote sensing datasets from European Commission's Joint Research Center, Ispra, Italy, the European Space Agency, and Boston University.

Edited by: A. Stenke

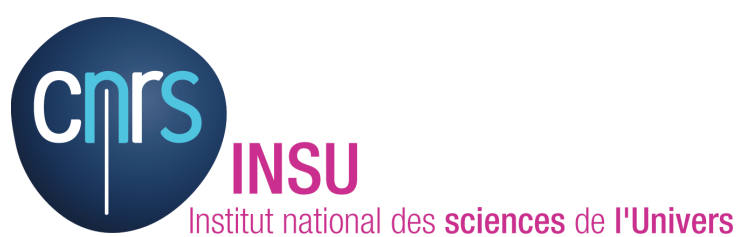

The publication of this article is financed by CNRS-INSU.

\section{References}

Alton, P., Fisher, R. A., Los, S. O., and Williams, M.: Simulations of global evapotranspiration using semiempirical and mechanistic schemes of plant hydrology, Global Biogeochem. Cy., 23, doi:10.1029/2009GB003540, 2009.

Arino, O., Bicheron, P., Achard, F., Latham, J., Witt, R., and Weber, J. L.: GLOBCOVER The most detailed portrait of Earth, ESA Bulletin-European Space Agency, 136, 24-31, 2008.

Baker, I. T., Prihodko, L., Denning, A. S., Goulden, M. L., Miller, S. D., and da Rocha, H. R.: Seasonal drought stress in the Amazon: Reconciling models and observations, J. Geophys. Res., 113, doi:10.1029/2007JG000644, 2008.

Bartholome, E. and Belward, A. S.: GLC2000: a new approach to global land cover mapping from Earth observation data, Int. J. Remote Sens., 26, 1959-1977, 2005.

Beer, C., Reichstein, M., Tomelleri, E., Ciais, P., Jung, M., Carvalhais, N., Rödenbeck, C., Arain, M. A., Baldocchi, D., Bonan, G., Bondeau, A., Cescatti, A., Lasslop, G., Lindroth, A., Lomas, M., Luyssaert, S., Margolis, H., Oleson, K. W., Roupsard, O., Veenendaal, E., Viovy, N., Williams, C., Woodward, F. I., and Papale, D.: Terrestrial gross carbon dioxide uptake: Global distribution and covariation with climate, Science, 329, 834-838, 2010.

Bonan, G. B., Levis, S., Kergoat, L., and Oleson, K. W.: Landscapes as patches of plant functional types: An integrating concept for climate and ecosystem models, Global Biogeochem. Cy., 16, doi:10.1029/2000GB001360, 2002.

Bondeau, A., Smith, P. C., Zaehle, S., Schaphoff, S., Lucht, W., Cramer, W., Gerten, D., Lotze-Campen, H., Müller, C., Reichstein, M., and Smith, B.: Modelling the role of agriculture for the 20th century global carbon balance, Glob. Change Biol., 13, 679-706, 2007.

Christensen, N. L. and Peet, R. K.: Convergence during secondary forest succession, J. Ecol., 65, 25-36, 1984

Collatz, G. J., Berry, J. A., and Clark, J. S.: Effects of climate and atmospheric $\mathrm{CO}_{2}$ partial pressure on the global distribution of C4 grasses: Present, past, and future, Oecologia, 114, 441-454, 1998.

DeFries, R., Hansen, M. C., Townshend, J. R. G., Janetos, A. C., and Loveland, T. R.: A new global 1-km dataset of percentage tree cover derived from remote sensing, Glob. Change Biol., 6, 247-254, 2000.

Dickinson, R. E., Oleson, K. W., Bonan, G. B., Hoffman, F., Thornton, P. E., Vertenstein, M., Yang, Z. L., and Zeng, X.: The Community Land Model and its climate statistics as a component of the Community Climate System Model, J. Climate, 19, 2302 2324, 2006.

Foley, J. A., Defries, R., Asner, G. P., Barford, C., Bonon, G., Carpenter, S. R., Chapin, F. S., Coe, M. T., Daily, G. C., Gibbs, H. K., Helkowski, J. H., Holloway, T., Howard, E. A., Kucharik, C. J., Monfreda, C., Patz, J. A., Prentice, I. C., Ramankutty, N., and Snyder, P. K.: Global consequences of land use, Science, 309, 570-574, 2005.

Friedl, M. A., McIver, D. K., Hodges, J. C. F., Zhang, X. Y., Muchoney, D., Strahler, A. H., Woodcock, C. E., Gopal, S., Schneider, A., Cooper, A., Baccini, A., Gao, F., and Schaaf, C. B.: Global Land Cover Mapping from MODIS: Algorithms and Early Results, Remote Sens. Environ., 83, 287-302, 2002. 
Friedl, M. A., Sulla-Menashe, D., Tan, B., Schneider, A., Ramankutty, N., Sibley, A., and Huang, X.: MODIS Collection 5 Global Land Cover: Algorithm refinements and characterization of new datasets, Remote Sens. Environ., 114, 168-182, 2010.

Fritz, S. and See, L.: Identifying and quantifying uncertainty and spatial disagreement in the comparison of Global Land Cover for different applications, Global Change Biol., 14, 1057-1075, 2008.

Gerten, D., Hoff, H., Bondeau, A., Lucht, W., Smith, P., and Zaehle, S.: Contemporary "green" water flows: Simulations with a dynamic global vegetation and water balance model, Phys. Chem. Earth, 30, 334-338, 2005.

Giri, C., Zhu, Z., and Reed, B.: A comparative analysis of the Global Land Cover 2000 and MODIS land cover data sets, Remote Sens. Environ., 94, 123-132, 2005.

Gurney, K. R., Law, R. M., Denning, A. S., Rayner, P., Baker, D., Bousquet, P., Bruhwiler, L., Chen, Y. H., Ciais, P., Fan, S., Fung, I. Y., Gloor, M., Heimann, M., Higuchi, K., John, J., Kowalczyk, E., Maki, T., Maksyutov, S., Peylin, P., Prather, M., Pak, B., Sarmiento, J., Taguchi, S., Takahashi, T., and Yuen, C. W.: TransCom $3 \mathrm{CO}_{2}$ inversion intercomparison: 1. Annual mean control results and sensitivity to transport and prior flux information, Tellus, 55B, 555-579, 2003.

Haberl, H., Erb, K. H., Krausmann, F., Gaube, V., Bondeau, A., Plutzar, C., Gingrich, S., Lucht, W., and Fischer-Kowalski, M.: Quantifying and mapping the human appropriation of net primary production in earth's terrestrial ecosystems, P. National Academy of Science, 104, 12942-12947, 2007.

Herold, M., Mayaux, P., Woodcock, C. E., Baccini, A., and Schmullius, C.: Some challenges in global land cover mapping: An assessment of agreement and accuracy in existing $1 \mathrm{~km}$ datasets, Remote Sens. Environ., 112, 2538-2556, 2008.

Hugh, E. D., Belward, A., De Miranda, E. E., Di Bella, C. M., Gond, V., Huber, O., Jones, S., Sgrenzaroli, M., and Fritz, S.: A land cover map of South America, Glob. Change Biol., 10, 731-744, 2004.

Jung, M., Henkel, K., Herold, M., and Churkina, G.: Exploiting synergies of global land cover products for carbon cycle modeling, Remote Sens. Environ., 101, 534-553, 2006.

Jung, M., Vetter, M., Herold, M., Churkina, G., Reichstein, M., Zaehle, S., Ciais, P., Viovy, N., Bondeau, A., Chen, Y., Trusilova, K., Feser, F., and Heimann, M.: Uncertainties of modeling gross primary productivity over Europe: A systematic study on the effects of using different drivers and terrestrial biosphere models, Glob. Biogeochem. Cy., 21, doi:10.1029/2006GB002915, 2007.

Kindermann, G., McCallum, I., Fritz, S., and Obersteiner, M.: A Global Forest Growing Stock, Biomass and Carbon Map Based on FAO Statistics, Silva Fennica, 42, 387-396, 2008.

Kleidon, A., Adams, J., Pavlick, R., and Reu, B.: Simulated geographic variations of plant species richness, evenness and abundance using climatic constraints on plant functional diversity, Environ. Res. Lett., 4, 014007, doi:10.1088/1748-9326/4/1/014007, 2009.

Klein Goldewijk, K. and Batjes, J. J.: A hundred year (1890-1990) database for integrated environmental assessments (HYDE, version 1.1), Bilthoven, the Netherlands, 1997.

Klein Goldewijk, K., van Drecht, G., and Bouwman, A. F.: Mapping contemporary global cropland and grassland distributions on a 5 x 5 minute resolution, J. Land Use Sci., 2, 167-190, 2007.
Kobayashi, H. and Dye, D. G.: Atmospheric conditions for monitoring the long-term vegetation dynamics in the Amazon using normalized difference vegetation index, Remote Sens. Environ., 97, 519-525, 2005.

Köppen, W.: Das geographisca System der Klimate, in: Handbuch der Klimatologie, edited by: Köppen, W., and Geiger, G., 1. C. Gebr, Borntraeger, 1-44, 1936.

Krinner, G., Viovy, N., de Noblet-Ducoudré, N., Ogeé, J., Polcher, J., Friedlingstein, P., Ciais, P., Sitch, S., and Prentice, I. C.: A dynamic global vegetation model for studies of the coupled atmosphere-biosphere system, Glob. Biogeochem. Cy., 19, GB1015, doi:1010.1029/2003GB002199, 2005.

Lapola, D. M., Oyama, M. D., Nobre, C. A., and Sampaio, G.: A new world natural vegetation map for global change studies, Annals of the Brazilian Academy of Science, 80, 397-408, 2008.

Lawrence, P. J. and Chase, T. N.: Representing a MODIS Consistent Land Surface in the Community Land Model (CLM 3.0): Part 1 Generating MODIS Consistent Land Surface Parameters, J. Geophys. Res., 112, doi:10.1029/2006JG000168, 2007.

Lefsky, M. A.: A global forest canopy height map from the Moderate Resolution Imaging Spectroradiometer and the Geoscience Laser Altimeter System, Geophys. Res. Lett., 37, doi:10.1029/2010GL043622, 2010.

Legates, D. R. and Wilmott, C. J.: Mean seasonal and spatial variability in global surface air temperature, Theor. Appl. Climatol., 41, 11-21, 1990.

Legendre, P., Borcard, D., and Peres-Neto, P. R.: Analyzing beta diversity: Partitioning the spatial variation of community composition data, Ecol. Monogr., 75, 435-450, 2005.

Loucks, C. J., Ricketts, T. H., Naidoo, R., Lamoreux, J. F., and Hoekstra, J. M.: Explaining the global pattern of protected area coverage: relative importance of vertebrate biodiversity, human activities and agricultural suitability, J. Biogeogr., 35, 13371348, 2008.

Matthews, E.: Global vegetation and land use: New high-resolution data bases for climate studies, J. Clim. Appl. Meteorol., 22, 474487, 1983.

Mitchell, C. D. and Jones, P.: An improved method of constructing a database of monthly climate observations and associated highresolution grids, Int. J. Climatol., 25, 693-712, 2005.

Morton, D. C., DeFries, R. S., Shimabukuro, Y. E., Anderson, L. O., Arai, E., del Bon Espirito-Santo, F., Freitas, R., and Morisette, J. T.: Cropland expansion changes deforestation dynamics in the southern Brazilian Amazon, P. National Academy of Science, 103, 14637-14641 2006.

Nemani, R. R., Keeling, C. D., Hashimoto, H., Jolly, W. M., Piper, S. C., Tucker, C. J., Myneni, R. B., and Running, S.: ClimateDriven Increases in Global Terrestrial Net Primary Production from 1982 to 1999, Science, 300, 1560-1563, 2003.

New, M., Lister, D., Hulme, M., and Makin, I.: A high-resolution data set of surface climate over global land areas, Clim. Res., 21, $1-25,2002$.

Oki, T. and Kanae, S.: Global hydrological cycles and world water resources, Science, 313, 1068-1072, 2006.

Olson, J., Watts, J. A., and Allison, L. J.: Carbon in Live Vegetation of Major World Ecosystems, ORNL-5862, Oak Ridge National Laboratory, Oak Ridge, Tennessee, 164 pp., 1983.

Peel, M. C., Finlayson, B. L., and McMahon, T. A.: Updated world map of the Kppen-Geiger climate classification, Hydrol. 
Earth Syst. Sci., 11, 1633-1644, doi:10.5194/hess-11-16332007, 2007.

Plummer, S.: Perspectives on combining ecological process models and remotely sensed data, Ecol. Model., 129, 169-186, 2000.

Poulter, B. and Cramer, W.: Satellite remote sensing of tropical forest canopies and their seasonal dynamics, Int. J. Remote Sens., 30, 6575-6590, 2009.

Poulter, B., Heyder, U., and Cramer, W.: Modelling the sensitivity of the seasonal cycle of GPP to dynamic LAI and soil depths in tropical rainforests, Ecosystems, 12, 517-533, 2009.

Prentice, I. C., Cramer, W., Harrison, S. P., Leemans, R., Monserud, R. A., and Soloman, A. M.: A global biome model based on plant physiology and dominance, soil properties and climate, J. Biogeogr., 19, 117-134, 1992.

Quaife, T., Quegan, S., Disney, M., Lewis, P., Lomas, M. R., and Woodward, F. I.: Impact of land cover uncertainties on estimates of biospheric carbon fluxes, Glob. Biogeochem.1 Cy., 22, doi:10.1029/2007GB003097, 2008.

Ramankutty, N. and Foley, J. A.: Characterizing patterns of global land use: An analysis of global croplands data, Glob. Biogeochem. Cy., 12, 667-685, 1998.

Rotenberg, E. and Yakir, D.: Contribution of semi-arid forests to the climate system, Science, 327, 451-454, 2010.

Running, S., Loveland, T. R., Pierce, L. L., Nemani, R. R., and Hunt, E. R.: A remote sensing based vegetation classification logic for global land cover analysis, Remote Sens. Environ., 51, 39-48, 1995.

Saleska, S. R., Didan, K., Huete, A. R., and da Rocha, H. R.: Amazon forests green-up during 2005 drought, Science, 318, 612, 2007.

Samanta, A., Ganguly, S., Hashimoto, H., Devadiga, S., Vermote, E. F., Knyazikhin, Y., Nemani, R. R., and Myneni, R. B.: Amazon forests did not green-up during the 2005 drought, Geophys. Res. Lett., 37, doi:10.1029/2009GL042154 2010.

Scheiter, S. and Higgins, S. I.: Impacts of climate change on the vegetation of Africa: an adaptive dynamic vegetation modelling approach, Glob. Change Biol., 15, 2224-2246, 2009.

Schimel, D. S., House, J. I., Hibbard, K., Bousquet, P., Ciais, P., Peylin, P., Braswell, B., Apps, M. J., Baker, D., Bondeau, A., Canadell, J. G., Churkina, G., Cramer, W., Denning, A. S., Field, C. B., Friedlingstein, P., Goodale, C., Heimann, M., Houghton, R. A., Melillo, J. M., Moore III, B., Murdiyarso, D., Noble, I. P., S.W., Prentice, I. C., Raupach, M., Rayner, P., Scholes, R. J., Steffen, W., and Wirth, C.: Recent patterns and mechanisms of carbon exchange by terrestrial ecosystems, Nature, 414, 169$172,2001$.
Sitch, S., Smith, B., Prentice, I. C., Arneth, A., Bondeau, A., Cramer, W., Kaplan, J. O., Levis, S., Lucht, W., Sykes, M. T., Thonicke, K., and Venevsky, S.: Evaluation of ecosystem dynamics, plant geography and terrestrial carbon cycling in the LPJ dynamic global vegetation model, Glob. Change Biol., 9, 161185, 2003.

Smith, T. M., Shugart, H. H., and Woodward, F. I.: Plant functional types: their relevance to ecosystem properties and global change, Cambridge University Press, New York, 369 pp., 1997.

Sterling, S. and Ducharne, A.: Comprehensive data set of global land cover change for land surface model applications, Glob. Biogeochem. Cy., 22, doi:10.1029/2007GB002959, 2008.

Still, C. J., Berry, J. A., Collatz, G. J., and DeFries, R.: Global distribution of $\mathrm{C} 3$ and $\mathrm{C} 4$ vegetation: Carbon cycle implications, Glob. Biogeochem. Cy., 17, doi:10.1029/2001GB001807, 2003.

Sun, W., Liang, S., Xu, G., Fang, H., and Dickinson, R. E.: Mapping plant functional types from MODIS data using multisource evidential reasoning, Remote Sens. Environ., 112, 1010-1024, 2008.

Thonicke, K., Venevsky, S., Sitch, S., and Cramer, W.: The role of fire disturbance for global vegetation dynamics: coupling fire into a Dynamic Global Vegetation Model, Global Ecol. Biogeogr., 10, 661-677, 2001.

Ustin, S. L. and Gamon, J. A.: Remote sensing of plant functional types, New Phytologist, 186, 795-816, 2010.

Verant, S., Laval, K., Polcher, J., and De Castro, M.: Sensitivity of the continental hydrological cycle to the spatial resolution over the Iberian Peninsula, J. Hydrometeorol., 5, 267-285, 2004.

Wang, A., Price, D. T., and Arora, V. K.: Estimating changes in global vegetation cover (1850-2100) for use in climate models, Global Biogeochem. Cy., 20, doi:10.1029/2005GB002514, 2006.

Whittaker, R. H.: Evolution and measurement of species diversity, Taxon, 21, 213-251, 1972.

Zobler, L.: A world soil file for global climate modeling, NASA Technical Memorandum, 32 pp., 1986. 